\title{
Transcriptional Mechanisms Underlying Hemoglobin Synthesis
}

\author{
Koichi R. Katsumura, Andrew W. DeVilbiss, Nathaniel J. Pope, Kirby D. Johnson, \\ and Emery H. Bresnick
}

Department of Cell and Regenerative Biology, UW-Madison Blood Research Program, Wisconsin Institute for Medical Research, Carbone Cancer Center, University of Wisconsin School of Medicine and Public Health, Madison, Wisconsin 53705

Correspondence: ehbresni@wisc.edu

The physiological switch in expression of the embryonic, fetal, and adult $\beta$-like globin genes has garnered enormous attention from investigators interested in transcriptional mechanisms and the molecular basis of hemoglobinopathies. These efforts have led to the discovery of cell type-specific transcription factors, unprecedented mechanisms of transcriptional coregulator function, genome biology principles, unique contributions of nuclear organization to transcription and cell function, and promising therapeutic targets. Given the vast literature accrued on this topic, this article will focus on the master regulator of erythroid cell development and function GATA-1, its associated proteins, and its frontline role in controlling hemoglobin synthesis. GATA-1 is a crucial regulator of genes encoding hemoglobin subunits and heme biosynthetic enzymes. GATA-1-dependent mechanisms constitute an essential regulatory core that nucleates additional mechanisms to achieve the physiological control of hemoglobin synthesis.

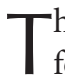
he transcriptional switch from embryonic to fetal, and subsequently to adult globin gene transcription constitutes an elegant mechanism to meet the unique developmental requirements for oxygenation of cells and tissues during gestation (Blau and Stamatoyannopoulos 1994; Orkin and Higgs 2010; Sankaran and Orkin 2013). Mechanistic studies on this problem have a dual motivation. Investigators studying transcriptional mechanisms in erythroid cells have accrued an impressive track record with respect to forging principles of gene and chromosome regulation that have broad relevance to diverse systems. Furthermore, preva- lent hemoglobin-associated pathologies (sickle cell anemia, additional anemias, thalassemias, and developmental disorders) constitute a major public health problem worldwide (Weatherall 2010). Elevating expression of the developmentally silenced $\gamma$-globin gene can supplant mutant or inadequate levels of $\beta$-globin in human disease states, thereby suppressing the associated symptoms (Rodgers et al. 1989; Bunn 1999; Atweh and Schechter 2001; Orkin and Higgs 2010). Thus, dissecting mechanisms controlling hemoglobin biosynthesis in exquisite detail is expected to yield novel molecular strategies for the treatment of hemoglobinopathies.

Editors: David Weatherall, Alan N. Schechter, and David G. Nathan

Additional Perspectives on Hemoglobin and Its Diseases available at www.perspectivesinmedicine.org

Copyright (C) 2013 Cold Spring Harbor Laboratory Press; all rights reserved; doi: 10.1101/cshperspect.a015412

Cite this article as Cold Spring Harb Perspect Med 2013;3:a015412 
K.R. Katsumura et al.

Other articles in this collection have highlighted the molecular biology of genes encoding hemoglobin subunits (Hardison 2012), hemoglobinopathies (Nienhuis and Nathan 2012; Higgs 2013), and human genetic studies that revealed an extremely important new regulator of hemoglobin switching, the transcriptional coregulator BCL11A (Lettre 2012; Sankaran and Orkin 2013). Undoubtedly, BCL11A is a crucial component of the hemoglobin switching machinery, and major efforts are under way to elucidate how BCL11A functions in physiological and pathological contexts. As transcriptional coregulators almost invariably function in large heteromeric protein complexes, one would expect a host of established and undiscovered BCL11A interactors (either direct or indirect) to have integral roles in hemoglobin switching. Independent of BCL11A, additional factors (e.g., the master regulator of erythrocyte development and function GATA-1) (Evans and Felsenfeld 1989; Tsai et al. 1989; Yamamoto et al. 1990; Zon et al. 1990), regulate hemoglobin synthesis, and initial studies imply potentially important functional links to BCL11A-dependent mechanisms.

Whereas the exciting BCL11A work (Menzel et al. 2007a; Lettre et al. 2008; Sankaran et al. 2008, 2009, 2010b; Uda et al. 2008; Xu et al. 2010) has inarguably energized this extremely important field, more than a decade of studies have highlighted the essential role of GATA- 1 as a critical determinant of hemoglobin synthesis. GATA-1 directly regulates expression of genes encoding hemoglobin subunits and heme biosynthetic enzymes (Johnson et al. 2002; Cheng et al. 2009; Fujiwara et al. 2009; Yu et al. 2009). Elucidating mechanisms underlying GATA-1 function/regulation is essential to achieve a holistic perspective of hemoglobin synthesis, which will naturally lead to rational approaches to therapeutically modulate hemoglobin switching. The transcriptional control of hemoglobin synthesis has multiple regulatory layers, all contributing essential functions. GATA-1 establishes the erythroid-specific chromatin structure of the $\alpha$ - and $\beta$-like globin gene clusters (Stamatoyannopoulos et al. 1995; Pomerantz et al. 1998; Goodwin et al. 2001; Letting et al. 2003;
Anguita et al. 2004; Im et al. 2005; Kim et al. 2007; Fujiwara et al. 2009; Wu et al. 2011) and participates in various mechanistic steps to ensure expression of the globin genes in a developmental stage-appropriate manner. Thus, GATA- 1 creates a regulatory core, on which additional mechanisms (e.g., those involving BCL11A), are seamlessly integrated to yield the complete regulatory system. Without GATA-1, the active loci would likely revert into repressive chromatin structures resembling nonerythroid cells, and erythroblasts would lose the capacity to survive.

\section{GATA FACTOR MECHANISMS AND BIOLOGY}

Efforts to understand globin gene regulation led to the discovery of a simple DNA sequence, $(\mathrm{A} / \mathrm{T}) \operatorname{GATA}(\mathrm{A} / \mathrm{G})($ WGATAR $=$ GATA motif $)$, that commonly resides at cis-regulatory elements of globin promoters and enhancers (Evans et al. 1988). This discovery paved the way for the cloning of the erythroid protein that binds this sequence, the founding member of the GATA factor family, GATA-1 (Evans and Felsenfeld 1989; Tsai et al. 1989; Yamamoto et al. 1990). Impressively, GATA-1 regulates hundreds of genes (Welch et al. 2004; Fujiwara et al. 2009; Yu et al. 2009) that mediate the development and function of erythroid cells (Pevny et al. 1991, 1995; Simon et al. 1992; Fujiwara et al. 1996). The cloning of GATA-1 ushered in the discovery of related GATA factors (GATA-2-6) (Wilson et al. 1990; Yamamoto et al. 1990; Ho et al. 1991; Lee et al. 1991; Dorfman et al. 1992; Arceci et al. 1993; Ito et al. 1993; Kelley et al. 1993; Tsai et al. 1994; Morrisey et al. 1996, 1997; Kuo et al. 1997; Molkentin et al. 1997), which almost invariably differ from GATA-1 in expression patterns and functions in systems including the brain, heart, vasculature, and skin. A hallmark attribute of GATA factors is their diagnostic dual zinc finger motif (Fig. 1) (Liew et al. 2005; Gamsjaeger et al. 2007). The zinc finger closest to the carboxyl terminus of GATA-1 (carboxyl finger) mediates sequence-specific DNA binding (Martin and Orkin 1990; Ko and Engel 1993; Merika and Orkin 1993), whereas the zinc finger closest to the GATA-1 amino terminus (amino finger) 
Mechanisms Underlying Hemoglobin Synthesis

A

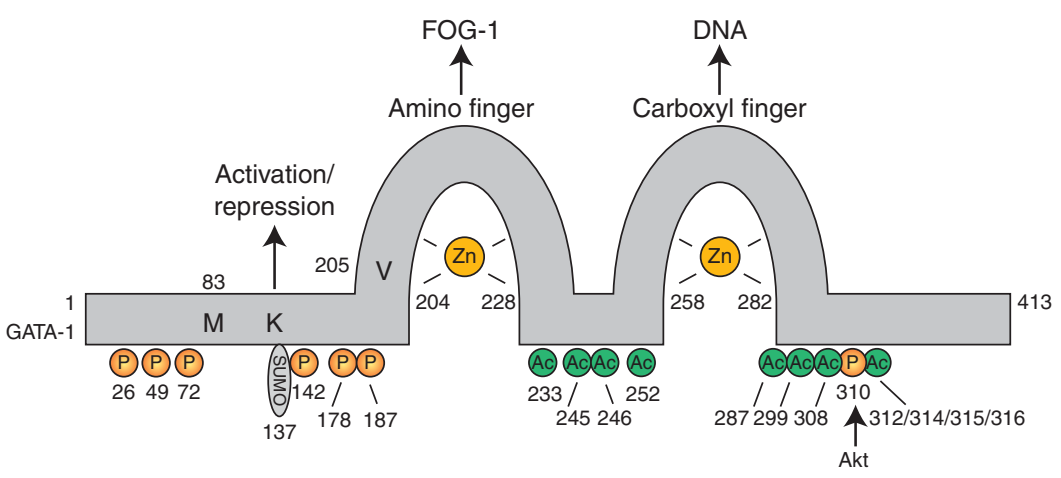

B

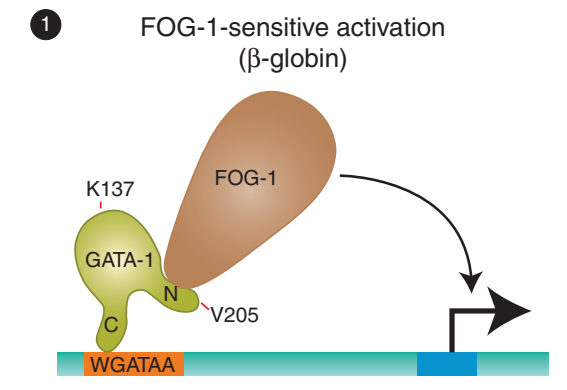

3 FOG-1-sensitive repression (Gata2)

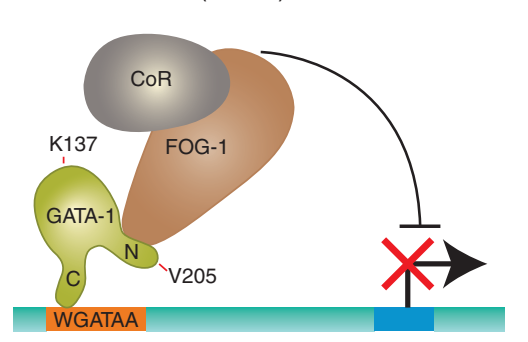

C

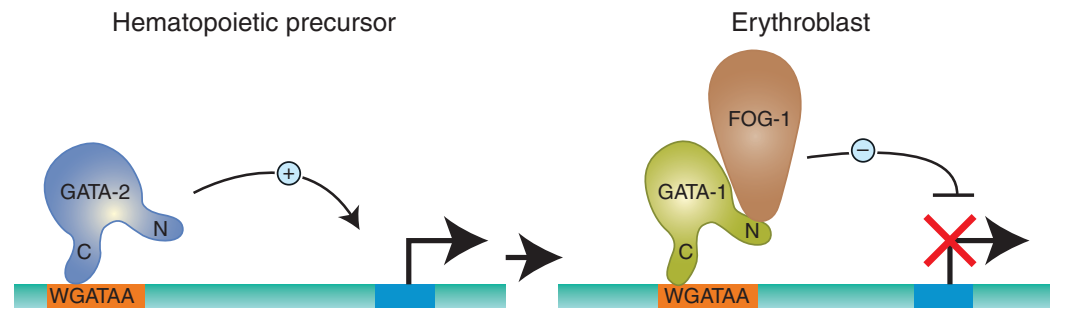

2 FOG-1-insensitive activation (Epb49)

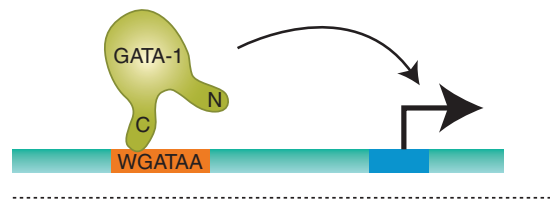

(4) FOG-1-insensitive repression $(L y / 1)$

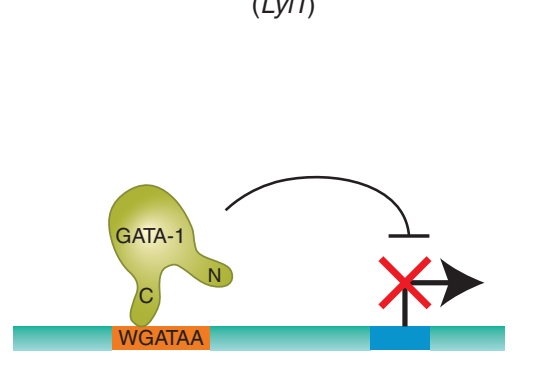

Erythroblast
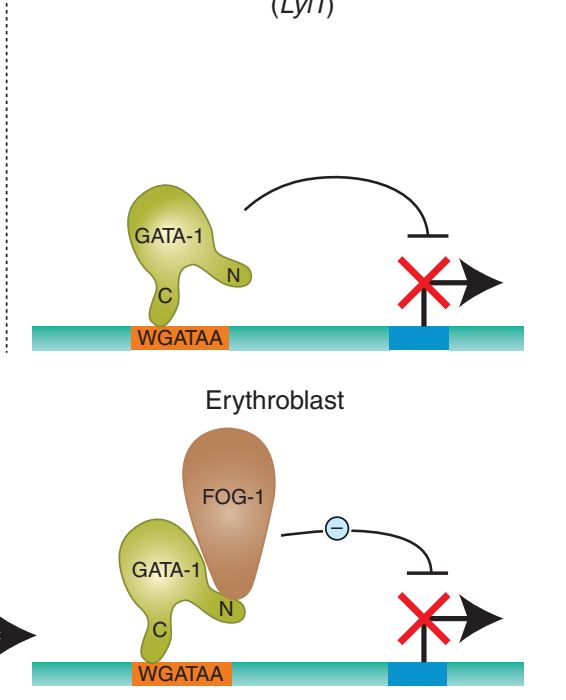

Figure 1. The molecular basis of GATA-1 action. (A) Diagram of GATA-1 protein organization illustrating the amino and carboxyl fingers and posttranslational modification sites. The amino finger mediates FOG-1 binding, whereas the carboxyl finger mediates sequence-specific DNA binding to GATA motifs. M83 is an alternative translation start site of a leukemogenic form of GATA-1 in acute megakaryoblastic leukemia (Wechsler et al. 2002; Crispino 2005). V205 is mutated in dyserythropoietic anemia and thrombocytopenia (Nichols et al. 2000), and facilitates FOG-1 binding (Crispino et al. 1999). Phosphorylation (P) (Crossley and Orkin 1994; Towatari et al. 2004; Kadri et al. 2005; Yu et al. 2005; Zhao et al. 2006) and acetylation (Ac) (Hung et al. 1999; Lamonica et al. 2006, 2011) sites are depicted, as well as a sumoylated site (Collavin et al. 2004; Lee et al. 2009). (B) Multiple modes of GATA-1 function. GATA-1 activates or represses its target genes with or without FOG-1. (Legend continues on following page.) 
K.R. Katsumura et al.

binds the cell type-restricted transcriptional coregulator Friend of GATA-1 (FOG-1) (Tsang et al. 1997, 1998; Crispino et al. 1999). The amino fingers of other GATA factors (e.g., GATA-4 and GATA-6) bind the FOG-1-related coregulator FOG-2 (Lu et al. 1999; Svensson et al. 1999; Tevosian et al. 1999, 2000). FOG-1 and FOG-2 each contain nine zinc fingers, none of which have been shown to mediate DNA binding (Gamsjaeger et al. 2007). However, four zinc fingers of FOG-1 are implicated in binding the GATA-1 amino finger (Fox et al. 1999; Cantor et al. 2002). FOG-1 interaction partners include the chromatin remodeling/modifying nucleosome remodeling and histone deacetylase (NuRD) complex (Hong et al. 2005; Gregory et al. 2010; Miccio et al. 2010), the corepressor CtBP (Holmes et al. 1999; Katz et al. 2002; Snow et al. 2010a), and the centrosomal protein transforming acidic coiled coiled 3 (TACC3) (GarrigaCanut and Orkin 2004; Simpson et al. 2004).

The intimation that GATA-1 would be a universally important regulator of erythroid gene expression was definitively established through loss-of-function studies in embryonic stem cells and mice (Pevny et al. 1991, 1995; Simon et al. 1992; Weiss et al. 1994; Weiss and Orkin 1995; Fujiwara et al. 1996) and via human disease-associated GATA-1 mutations (Nichols et al. 2000; Crispino 2005). The targeted deletion of GATA1 yielded embryonic lethality at E10.5-11.5 and a striking disruption of erythroid cell development and maturation (Fujiwara et al. 1996). Consistent with its expression in select additional hematopoietic lineages, GATA-1 is also required for the development and maturation of megakaryocytes, eosinophils, and mast cells (Zon et al. 1991; Vyas et al. 1999; Hirasawa et al. 2002; Yu et al. 2002; Migliaccio et al. 2003; Humbles et al. 2004; Cantor et al. 2008; Sugiyama et al.
2008; Huang et al. 2009). The critical importance of FOG-1 as a GATA-1 coregulator was also established through gene-targeting studies in the mouse. FOG-1 nullizygous mouse embryos die at an embryonic stage similar to that of GATA-1 nullizygous embryos (E10.5-E11.5) and show defective erythropoiesis and megakaryopoiesis (Tsang et al. 1998). Furthermore, a V205M mutation in the GATA-1 amino finger disrupts the GATA-1-FOG-1 interaction, resulting in familial dyserythropoietic anemia and thrombocytopenia (Nichols et al. 2000).

The extraordinarily important biological functions of GATA-1 and FOG-1 provided the impetus for intense efforts to elucidate their mechanisms of action. Analogous to numerous trans-acting factors, GATA factors can activate and repress transcription (Kim and Bresnick 2007; Bresnick et al. 2010). Mechanistic studies to drill deeply into GATA-1-dependent transcriptional mechanisms are ongoing. FOG-1 mediates the majority of GATA-1-dependent transcriptional responses (Johnson et al. 2007; Chlon et al. 2012), and FOG-2 is used by other GATA factors. Although many questions remain unanswered regarding FOG-1 and FOG2 mechanisms, FOG-1 has a chromatin occupancy facilitator activity (Letting et al. 2004; Pal et al. 2004) that increases GATA-1 chromatin occupancy at certain, but not all, chromatin sites and suppresses GATA- 1 from accessing another cohort of sites (Johnson et al. 2006; Chlon et al. 2012). GATA-2 frequently occupies chromatin sites before GATA-1 during hematopoiesis (Grass et al. 2003, 2006; Bresnick et al. 2005, 2010, 2012; Martowicz et al. 2005; Kim and Bresnick 2007; Lugus et al. 2007; Fujiwara et al. 2009; Dore et al. 2012). When GATA-1 levels increase during erythropoiesis, it displaces GATA-2 from chromatin, including sites at the Gata2 gene.

Figure 1. (Continued) The precise mode of transcriptional control is locus-specific, and representative target genes that conform to each regulatory mode are depicted (Bresnick et al. 2012). (C) GATA switch model. GATA switches are defined as a molecular transition in which one GATA factor replaces another from a chromatin site, which is often associated with an altered transcriptional output. In hematopoietic stem cells, select progenitors, and early-stage erythroblasts, GATA-2 occupies target loci. During erythropoiesis, poorly understood signals induce GATA-1 expression, and GATA-1 acquires the capacity to displace GATA-2 from chromatin, including sites at the Gata2 locus, which results in transcriptional repression. FOG-1 facilitates GATA-1 occupancy at select chromatin sites and GATA switches. 
This "GATA switch" is often associated with altered transcriptional outputs of the respective genes (Bresnick et al. 2010, 2012). For example, GATA switches occur at five sites of the Gata2 locus and were initially correlated with Gata2 repression (Grass et al. 2003, 2006; Martowicz et al. 2005). However, targeted deletions of three of these sites individually revealed qualitatively distinct activities. The -1.8 site was essential to maintain Gata2 repression in late-stage erythroblasts (Snow et al. 2010b). The -2.8 and -1.8 sites conferred maximal Gata2 expression in hematopoietic precursors (Snow et al. 2010b, 2011). The most interesting of the sites, the intronic + 9.5 site, was essential for Gata2 expression in the fetal liver, for fetal liver hematopoietic stem and progenitor cell activity, and for conferring vascular integrity (Johnson et al. 2012). This cis-element targeting study provided the first example of an exceedingly important function for a GATA switch site in vivo. Similar results were obtained using a +9.5 site-driven Cre recombinase to conditionally delete a floxed Gata2 allele (Lim et al. 2012).

FOG-1 facilitates the GATA switch at the Gata2 locus, required for GATA-1 to repress Gata2 (Pal et al. 2004), which is important to ensure normal erythrocyte development and therefore normal hemoglobin synthesis. Constitutive overexpression of GATA-2 in bone marrow represses hematopoiesis (Persons et al. 1999). Analysis of a mutant mouse strain containing a knock-in FOG-1 allele defective in NuRD binding indicated that this interaction is important for activation and repression (Miccio et al. 2010). Furthermore, the FOG-1-NuRD interaction appears to be important for the GATA switch at the Gata2 locus (Gao et al. 2010). The GATA switch mechanism is applicable to the control of numerous erythroid genes (Pal et al. 2004; Bresnick et al. 2010; Dore et al. 2012), and as discussed later in this review, this mechanism has been implicated in $\gamma$-globin transcriptional regulation (Costa et al. 2012; Zhu et al. 2012).

A limited ensemble of direct GATA-1 target genes (occupied by endogenous GATA-1 [Cheng et al. 2009; Fujiwara et al. 2009; Yu et al. 2009; Kang et al. 2012] and regulated by GATA-1 in a genetic complementation assay in GATA-1-null erythroid precursor cells [Weiss et al. 1997]) are not particularly sensitive to a GATA-1 mutation that reduces FOG-1 binding (e.g., V205G or V205M) or to reducing the FOG-1 level (e.g., in a FOG-1 nullizygous hematopoietic precursor cell line [Cantor et al. 2002], or on siRNAmediated knockdown of FOG-1) (Crispino et al. 1999; Johnson et al. 2006, 2007; Lee et al. 2009). We have referred to these genes as "FOG-1-independent," but examples exist in which there appears to be a partial FOG-1 requirement, rather than absolute FOG-1 independence. This differs from the genes conventionally deemed to be "FOG-1-dependent," such as Gata2 (repressed) and $\beta$ major (activated), as GATA-1 is largely incapable of regulating these genes without FOG-1. Given the apparent spectrum of FOG1 sensitivities, we now refer to FOG-1-sensitive and -insensitive, rather than an absolute dependence or independence. The magnitude of the gene expression changes at FOG-1-insensitive genes can be considerable, and these genes include Lyl1 (repressed) (Johnson et al. 2007), which encodes an important transcriptional regulator of HSCs (Souroullas et al. 2009; Zohren et al. 2012) and EPB49 (activated) (Kim et al. 2007), which encodes an important component of the red cell cytoskeleton, dematin (Rana et al. 1993; Khanna et al. 2002; Mohseni and Chishti 2008). Whereas it is likely that this mode of GATA-1 transcriptional control has functional importance, why certain target genes lack the crucial FOG-1 requirement remains a black box. Of greatest importance for this review is the FOG-1-sensitive mechanism, as GATA-1 uses FOG- 1 to regulate the $\alpha$ - and $\beta$-like globin genes (Kim and Bresnick 2007).

Consistent with the conventional mechanism of metazoan transcriptional regulators, GATA factors control chromatin remodeling and modification. GATA-1 binds and recruits the histone/protein acetyltransferase CREBbinding protein (CBP/p300) to chromatin, inducing both GATA-1 acetylation and histone acetylation (Blobel et al. 1998; Hung et al. 1999). GATA-1 recruits the BRG1 subunit of the ATP-dependent chromatin remodeling complex SWI/SNF (Im et al. 2005; Kim et al. 2007, 
K.R. Katsumura et al.

2009a,b), and Brg1 hypomorphic mutant mice show significant anemia and impaired erythropoiesis (Bultman et al. 2005). In contrast to $\mathrm{CBP} / \mathrm{p} 300$ and BRG1, GATA-1 interacts with a component of the mediator complex Med1 (Crawford et al. 2002; Stumpf et al. 2006), which is not known to have chromatin remodeling and/or modifying activity. Med1 is a core component of the broadly expressed 1-2 MDa mediator complex, which consists of more than 30 subunits, the vast majority of which have no ascribed biochemical function (Conaway et al. 2005; Kornberg 2005). Med1 knockout mouse embryos are severely anemic and show reduced progenitor activity in the erythroid, but not myeloid, lineage (Crawford et al. 2002; Stumpf et al. 2006). A conditional Med1 knockout confirmed the cell-autonomous nature of the erythroid requirement for Med1 (Stumpf et al. 2010). Although GATA-1 recruits Med1 and FOG-1 similarly, Med 1 and FOG-1 differ quantitatively in their contributions to GATA-1 function. Knockdown studies indicate that Med1 amplifies GATA-1 target gene activation, whereas FOG-1 contributes to a much greater extent to GATA-1 function (Pope and Bresnick 2010).

As an important manifestation of its molecular activities, GATA-1 bound to distal cis-regulatory elements can induce chromatin looping, thus bringing a distal site in close proximity to a promoter (Vakoc et al. 2005). GATA-1 binding to the $\beta$-globin LCR repositions the LCR such that its proximity to the $\beta$ major promoter increases considerably (Vakoc et al. 2005). GATA1 can also induce higher-order chromosomal transitions, in which a target locus is expelled from the nuclear periphery, freeing the locus from potential inhibitory constraints imposed by the unique subnuclear environment at the periphery (Lee et al. 2009, 2011). FOG-1 promotes both looping (Vakoc et al. 2005; Kim et al. 2007) and subnuclear relocalization of loci (Lee et al. 2009, 2011). BRG1 (Kim et al. 2009b) and the Lim domain protein Ldb1 (Song et al. 2007) are also required to establish the $\beta$-globin locus LCR-promoter loop. Tiling the chromosomal region surrounding the $\beta$-globin locus with bacterial artificial chromosome probes and conducting three-dimensional (3D) immunofluo- rescence in situ hybridization (immunoFISH) revealed that GATA- 1 expels the $\beta$-globin locus, but not the neighboring chromosomal sequences, from the nuclear periphery (Lee et al. 2011). Both FOG-1 and K137-sumoylated GATA-1 are required for this GATA-1 activity, and it is facilitated by the erythroid Krüppellike factor KLF1 (Miller and Bieker 1993; Perkins et al. 1995) and the NuRD complex subunit Mi2 $\beta$ (Lee et al. 2011). KLF1 organizes numerous target genes within nuclear neighborhoods (Drissen et al. 2004; Schoenfelder et al. 2010). Looping and subnuclear relocalization of the $\beta$-globin locus, as measured by chromosome conformation capture $(3 \mathrm{C})$ and $3 \mathrm{D}$-immunoFISH assays, may be related or identical processes. Although it is not our intent to comprehensively review the precise details of GATA-1-dependent molecular and supramolecular transitions, many of which remain unresolved, dissecting these mechanisms in exquisite detail is expected to continue to yield pivotal insights into the control of hemoglobin synthesis and to uncover targets for therapeutic modulation of this crucial process.

\section{EVIDENCE LINKING GATA FACTORS TO THE CONTROL OF HEMOGLOBIN SYNTHESIS}

Studies on how GATA-1 regulates genes encoding hemoglobin subunits and heme biosynthetic enzymes have forged principles of GATA factor function and revealed important insights into mechanisms controlling hemoglobin synthesis. The presence of GATA motifs (WGATAR) at globin gene promoters and enhancers, as well as transient transfection studies with globin promoter and enhancer reporter genes, led to the view that GATA-1 controls hemoglobin synthesis (Evans et al. 1990; Orkin 1990). The application of ChIP technology to measure protein occupancy at endogenous loci revealed GATA-1 occupancy at loci encoding globin subunits and heme biosynthetic enzymes (Horak et al. 2002; Johnson et al. 2002; Kiekhaefer et al. 2002; Im et al. 2005; Cheng et al. 2009; Fujiwara et al. 2009; Yu et al. 2009). In a genetic complementation assay in GATA-1-null erythroid precursor cells (Weiss et al. 1997), GATA-1 occupancy of LCR sites precedes occupancy 
at the adult $\beta$ major promoter (Im et al. 2005; Kim et al. 2007). GATA-1 recruits RNA polymerase II (Pol II) to the LCR and subsequently to the promoter, which occurs concomitantly with transcriptional activation (Johnson et al. 2001, 2002, 2003; Im et al. 2005; Kim et al. 2007). Strikingly, however, numerous genomic sites harbor GATA motifs that bind GATA factors with high affinity in the context of naked DNA, but these sites are not occupied in cells (Bresnick et al. 2006). Despite the $\sim 7$ million GATA motifs (WGATAR) in the human genome, genome-wide ChIP-seq analysis showed that GATA-1 discriminates exquisitely among these sites (Fujiwara et al. 2009; Kang et al. 2012). Occupancy was detected at only $0.07 \%$ of sites containing WGATAR. Thus, the presence of a GATA motif at a chromosomal site, even when evolutionarily conserved, appears to have little to no predictive value as to whether the associated gene will be bound to or regulated by GATA- 1 .

Given the low frequency of GATA-1 occupancy at sites containing the conventional GATA motif WGATAR, the sequence requirements for occupancy in vivo might vary from those required for naked DNA binding, and/ or additional parameters beyond the presence of a high-affinity GATA motif may dictate GATA motif access in vivo. Genome-wide ChIP-seq studies provided evidence for the existence of a more complex GATA motif at GATA-1-occupied sites in erythroid cells $[(\mathrm{C} / \mathrm{G})(\mathrm{A} / \mathrm{T}) \mathrm{GATAA}(\mathrm{G} /$ A/C) (G/A/C)], which exists at 297,124 copies in the human genome (Fujiwara et al. 2009). Although the frequency of occupancy at these sites is an order of magnitude greater than at WGATAR, it remains quite low (0.7\%). GATA motifs often reside in close proximity to other cis-regulatory elements, and it is likely that the neighboring elements constitute an important parameter that dictates GATA motif access in chromatin. However, interrogation of GATA-1bound DNA sequences isolated by ChIP using de novo motif finding methodology has not revealed individual or combinations of sites with significant utility for predicting GATA-1 occupancy (Fujiwara et al. 2009; Kang et al. 2012). In megakaryocytes (Dore et al. 2012) and endothe-
Mechanisms Underlying Hemoglobin Synthesis

lial cells (Linnemann et al. 2011), additional cisregulatory elements show highly statistically significant enrichments at GATA-2-occupied sites, respectively, although it remains unclear whether the combinatorial usage of the multiple elements is an important determinant of GATA factor chromatin occupancy.

Analogous to the chromatin site discrimination problem, major work is required to unravel the determinants of whether GATA- 1 binding to chromatin activates or represses one or more neighboring target genes. GATA-1 and GATA-2 often colocalize on chromatin with the E-protein Scl/TAL1 (Wozniak et al. 2008), and Scl/ TAL1 colocalization correlates with activation in certain contexts (Cheng et al. 2009; Tripic et al. 2009; Yu et al. 2009); however, exceptions to this correlation exist. As noted above, FOG-1 mediates both activation and repression (Crispino et al. 1999). This is a particularly challenging issue, as transient transfection assays do not faithfully recapitulate the activation and repression functions of endogenous GATA-1-associated cis-regulatory elements. Sites that confer enhancer activity with reporter genes in transiently transfected cells and in transgenic mice do not invariably exert crucial activities at endogenous loci (Snow et al. 2010b, 2011).

Analyses of the $\beta$-globin LCR, a far upstream strong enhancer element consisting of four DNaseI hypersensitive sites (HSs) (Tuan and London 1984; Forrester et al. 1986, 1987; Grosveld. et al. 1987), have been particularly instructive for understanding long-range transcriptional mechanisms in which clusters of cisregulatory elements control distant promoters (Fig. 2). Targeted deletion of the four HSs of the LCR from the endogenous mouse genome severely impairs $\beta$-like globin gene expression (Epner et al. 1998; Reik et al. 1998; Bender et al. 2000a). Although GATA motifs confer DNaseI hypersensitivity and contribute to enhancer activities of the HSs (Philipsen et al. 1990, 1993; Pruzina et al. 1991, 1994; Ellis et al. 1993; Stamatoyannopoulos et al. 1995; Pomerantz et al. 1998; Goodwin et al. 2001), targeted deletion of the individual HSs, each containing GATA motifs and additional cis-regulatory elements, only incrementally influence $\beta$-like glo- 
K.R. Katsumura et al.
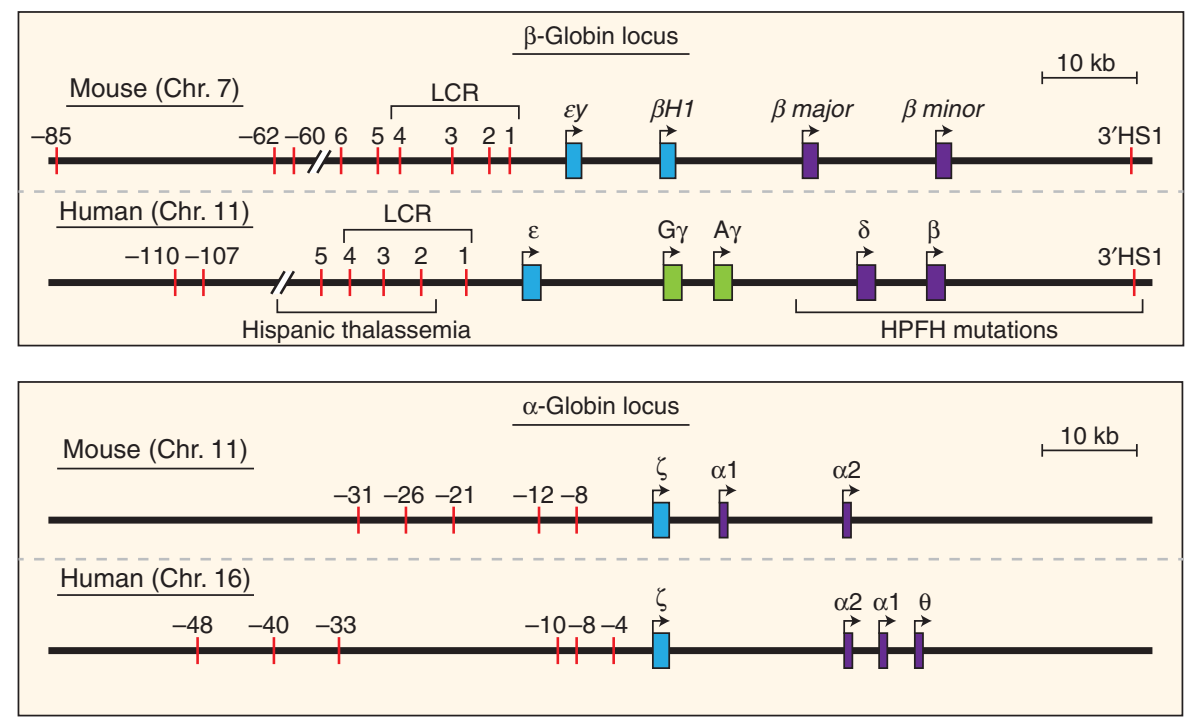

Figure 2. (Top) Organization of the human and murine $\beta$-globin loci. The human locus contains $\beta$-globin genes expressed during embryogenesis $(\varepsilon)$, fetal development (G $\gamma$ and $A \gamma$ ), and the adult ( $\delta$ and $\beta$ ). The mouse locus contains genes expressed during embryogenesis $(\varepsilon y$ and $\beta H 1)$ and adult ( $\beta$ major and $\beta$ minor). The regions identified in Hispanic thalassemia and hereditary persistence of fetal hemoglobin (HPFH) mutations are described. The genomic structure of the human and murine $\beta$-globin and $\alpha$-globin loci. Multiple DNaseI hypersensitive sites (HSs) are indicated by red bars. The human $\beta$-globin locus has five proximal HSs and additional HSs. The mouse locus has six proximal HSs and additional HSs. Among these HSs, HS1-4 are termed the locus control region (LCR). The LCR mediates high-level transcription of the $\beta$-globin-like genes. A large deletion of the LCR characterizes Hispanic thalassemia (Driscoll et al. 1989; Forrester et al. 1990). (Bottom) Organization of the human and murine $\alpha$-globin loci. The human locus contains $\alpha$-globin genes expressed during embryogenesis $(\zeta)$ and the adult $(\alpha 1, \alpha 2$, and $\theta)$. Similarly, the mouse locus contains $\alpha$-globin genes expressed during embryogenesis $(\zeta)$ and the adult $(\alpha 1$ and $\alpha 2)$. Analogous to the $\beta$-globin locus, there are several DNaseI HSs at the $\alpha$-globin locus. A large deletion including these HSs and $\zeta$ has been identified in several patients (Hatton et al. 1990). Among these HSs, HS-40 (corresponding to HS-26 in the mouse locus) is considered to be functionally important.

bin gene transcription (Fiering et al. 1995; Hug et al. 1996; Bender et al. 2000b). The targeted deletion studies indicated that multiple HSs function additively in vivo (Bender et al. 2001), which was surprising given the qualitatively and quantitatively distinct activities of the individual HSs in reporter gene and transgenic mouse assays (Ryan et al. 1989; Caterina et al. 1994; Bungert et al. 1995, 1999; Pawlik and Townes 1995; Ellis et al. 1996; Peterson et al. 1996; Navas et al. 1998, 2001). It is unclear whether the HS activities are considerably more important in promiscuous reporter assays and at ectopic chromosomal sites versus the endogenous locus, whether human and mouse LCR sequences have distinct activities, or whether compensatory mechanisms mask their important functions when they are removed from the genome, and all are potentially important possibilities to rigorously explore. Regardless, GATA-1 occupies multiple sites at the endogenous $\beta$-globin and $\alpha$-globin loci (Johnson et al. 2002; Anguita et al. 2004; Im et al. 2005; De Gobbi et al. 2007; Fujiwara et al. 2009), and it seems highly likely that some of these sites control endogenous globin gene transcription. Strikingly, a single nucleotide polymorphism upstream of the $\alpha$-globin locus generates a GATA motif that confers promoter activity, thereby disrupting regulation of the downstream $\alpha$-globin genes (De Gobbi et al. 2006).

Studies with $\beta$-globin locus transgenes have provided further evidence to support a model 
Mechanisms Underlying Hemoglobin Synthesis

in which the core GATA-1 regulatory function is a critical determinant of hemoglobin switching. A GATA motif at the $\varepsilon$-globin promoter $(-208)$ suppresses activity of the promoter in a $\beta$-globin locus transgene in adult mice (Raich et al. 1995). Similarly, a GATA motif at -566 and -567 relative to the $A \gamma$ and $\mathrm{G} \gamma$ globin genes participates in $\gamma$-globin silencing in definitive erythroid cells (Harju-Baker et al. 2008). A hereditary persistence of fetal hemoglobin (HPFH) mutation at the -566 site prevents assembly of the complex and sustains $\gamma$-globin expression at developmental stages in which $\gamma$-globin should be silenced. Taken together with evidence that GATA-1, FOG-1, and Mi2 $\beta$ occupy this site, and that an erythroid cellspecific Mi2 $\beta$ knockout elevates $\gamma$-globin expression from a $\beta$-YAC in mice (Costa et al. 2012), these factors assemble a repressive complex that controls hemoglobin switching. In contrast to these results with $\beta$-globin locus transgenes, a knock-in mouse strain expressing a mutant FOG-1 defective in NuRD complex binding from the endogenous FOG-1 locus crossed with a human $\beta$-globin locus transgenic line shows normal $\gamma$-globin silencing (Miccio and Blobel 2010). Thus, the FOG-1-NuRD interaction is apparently not required for silencing the $\gamma$-globin genes, although one cannot rule out the possibility that $\mathrm{NuRD}$, and/or specific components of $\mathrm{NuRD}$, are recruited to the locus independent of FOG-1. Studies in the K562 erythroleukemia cell model system and primary erythroid cells indicate that GATA-2 and the CCAAT box binding factor NF-Y participate in $\gamma$-globin gene activation, whereas GATA-1, BCL11A, and COUP-TFII confer repression through the same site (Zhu et al. 2012). This finding conforms to the GATA switch mechanism (Bresnick et al. 2005, 2010), in which GATA-1 replacement of GATA-2 from chromatin induces a distinct transcriptional output. In summary, endogenous GATA-1 chromatin occupancy, induction of $\beta$-globin gene expression in a genetic complementation assay, and molecular/cellular studies using diverse systems support a role for GATA-1 in establishing a physiological pattern of hemoglobin synthesis.

\section{INTEGRATING GATA FACTOR-DEPENDENT MECHANISMS WITH OTHER MODES OF CONTROLLING HEMOGLOBIN SYNTHESIS}

Variations in the level of fetal hemoglobin $(\mathrm{HbF})$ in sickle cell disease (SCD) patients paved the way for the discovery of genetic modulators of hemoglobin switching. Genome-wide association studies identified SNPs that correlate with higher levels of $\mathrm{HbF}$, including QTLs near the $H B S 1 L-M Y B$ locus and the $\beta$-globin gene cluster, which were described previously, along with several QTLs at the BCL11A locus (Menzel et al. 2007b; Lettre et al. 2008; Uda et al. 2008). The HBS1L-MYB intergenic region associated with high $\mathrm{HbF}$ has HSs that are occupied by GATA-1 in human erythroid precursor cells (Wahlberg et al. 2009). In addition, GATA-1 down-regulates $M y b$ expression (Bartunek et al. 2003; Welch et al. 2004). Reduction of $M Y B$ mRNA by miRNA-15a and -16-1 in primary human erythroid cells results in elevated $\varepsilon$ and $\gamma$-globin synthesis (Sankaran et al. 2011). In comparison to the SNPs at the HBS1L-MYB and $\beta$-globin loci, the high-HbF-associated allele at rs4671393 in the BCL11A locus was the strongest indicator of fetal hemoglobin levels in a Brazilian cohort with SCD (Lettre et al. 2008). These studies led to the hypothesis that disruption of BCL11A modulates HbF levels, and therefore BCL11A represents a target for therapeutic intervention in SCD and $\beta$-thalassemia.

Recent studies have made the exceptionally interesting link between BCL11A activity to control hemoglobin switching and GATA-1 function. Proteomic analysis revealed interactions between expressed BCL11A and GATA-1, FOG-1, and the NuRD complex in cultured erythroid cells (Sankaran et al. 2008). BCL11A also interacts with the transcription factor Sox6, a regulator of $\gamma$-globin transcription (Yi et al. 2006; Xu et al. 2010). ChIP-chip analysis in primary human erythroid precursors revealed BCL11A occupancy at HSs of the $\beta$-globin LCR, which are also occupied by GATA-1 and Pol II. 3C analysis of the human $\beta$-globin locus in a $\beta$-YAC transgenic mouse crossed to a wild-type or Bcl11 $a^{-/-}$mouse indicated that 
K.R. Katsumura et al.

deletion of BCL11A reconfigures the higherorder chromatin structure of the locus (Xu et al. 2010). The LCR-dependent chromatin loop normally positions the LCR in close proximity to the $\beta$-globin promoter, but in this case, the LCR engages the G $\gamma$ and A $\gamma$ promoters. Although this intriguing mechanism has not been described in the context of the endogenous $\beta$-globin locus, these studies indicate that BCL11A can interact with GATA-1, and both factors regulate chromatin looping at the $\beta$-globin locus.

The conditional knockout of Bcl11a using EpoR-Cre + mice crossed to $\beta$-YAC transgenic mice prevented complete silencing of human $\gamma$-globin from the $\beta$-YAC (Xu et al. 2011). Genome-wide analysis indicates that this modulation of fetal globin expression is exquisitely specific, as the vast majority of genes were unaffected. Importantly, adult $\beta$-globin expression and other regulators of $\beta$-like globin genes, including KLF1 (Miller and Bieker 1993; Perkins et al. 1995), are unaffected by loss of BCL11A. Bcl11a knockout synergizes with HbF modulators, including the DNA methylation inhibitor 5-aza-2'-deoxycytidine (DAC), and the histone deacetylase (HDAC) inhibitor suberoylanilide hydroxamic acid (SAHA), to further increase $\gamma$-globin expression. Crossing the conditional Bcl11a knockout to the Berkeley SCD mouse model increases $\mathrm{HbF}$ expression, and corrects multiple SCD clinical parameters.

Genome-wide association studies in $27 \mathrm{Mal}-$ tese family members with HPFH identified a locus with strong association to high $\mathrm{HbF}$ levels at 19p13.12-13, which contains the gene encoding the erythroid Krüppel-like factor EKLF (KLF1) (Borg et al. 2010). Genomic sequencing of this cohort revealed a deletion that disrupts the zinc finger domain of KLF1, rendering it defective for DNA binding. The resulting KLF1 haploinsufficiency was accompanied by a decrease in BCL11A expression and an increase in the $\gamma$-globin to $\alpha$-globin ratio. A knockout of the HS1 enhancer upstream of the Klf1 gene greatly reduced KLF1 and BCL11A expression (Zhou et al. 2010). KLF1 occupies the murine $B c l 11 a$ promoter in bone marrow-derived Ter $119^{+}$cells, and the human $B C L 11 A$ promoter in erythroid progenitors isolated from peripheral blood (Borg et al. 2010; Zhou et al. 2010). KLF1 does not occupy the human BCL11A promoter in fetal liver erythroid progenitors, and KLF1 directly binds and activates the $H B B$ gene in adult but not fetal cells. KLF1 expression is elevated in adult erythroid precursors versus fetal erythroid precursors (Zhou et al. 2006). In aggregate, these data suggest that KLF1 directly regulates the switch from fetal to adult hemoglobin by binding to and activating the $H B B$ gene and indirectly triggers the switch via activating $B C L 11 A$, which in turn suppresses fetal globin gene expression. As GATA-1 can directly induce KLF1 expression (Crispino et al. 1999; Kim et al. 2007), this constitutes another critical link between the core GATA-1 regulatory function and hemoglobin switching.

In addition to the obviously crucial KLF1BCL11A axis for regulating hemoglobin switching, additional factors and mechanisms are implicated in controlling this crucial process (Jane et al. 1995; Filipe et al. 1999; Lopez et al. 2002; Tanabe et al. 2002, 2007; Pace et al. 2003; Basu et al. 2005; Bank 2006; Rupon et al. 2006, 2011; Sangerman et al. 2006; Yi et al. 2006; Bottardi et al. 2009; Sripichai et al. 2009; Yao et al. 2009; Sankaran et al. 2010a; Campbell et al. 2011; Wilber et al. 2011; Funnell et al. 2012; Ross et al. 2012). Many important questions remain, however, regarding the underlying mechanisms and biology, including whether the mechanisms are intricately linked to, or perhaps independent of, GATA-1 and KLF1-BCL11A. Furthermore, it will be important to elucidate the relevance of specific components of the switching machinery to existing and new preclinical and clinical approaches for therapeutically modulating $\gamma$-globin expression (Fibach et al. 1993; Rodgers et al. 1993; Fucharoen et al. 1996; Watanapokasin et al. 2005; Weinberg et al. 2005; Sangerman et al. 2006; Lavelle et al. 2008; Mabaera et al. 2008; Macari and Lowrey 2011; Wilber et al. 2011; Kutlar et al. 2012; Macari et al. 2012). Finally, almost undoubtedly, new mechanistic insights will launch leveraging opportunities to develop novel molecularly targeted therapies, although this will require sustained intense experimental efforts, while being particularly cautious not 
to fast-forward such initiatives in the absence of compelling mechanistic, biological, and/or pharmacological foundations. Clearly, the mechanistic infrastructure is insufficient at the present time to divert major efforts into applied therapeutics development and clinical optimization of existing strategies that are often less efficacious than desired.

As BCL11A has unequivocally emerged as an extremely important constituent in the regulation of hemoglobin switching, it represents an attractive target for therapeutic modulation of this process. However, developing efficacious BCL11A targeting strategies is not without significant challenges. Challenges include those intrinsic to drug design, as BCL11A is a zinc finger transcription factor without obvious binding pockets that can accommodate inhibitory drug docking. Second, as mentioned previously, the whole body knockout of BCL11A results in postnatal death (Liu et al. 2003). Although BCL11A deletion does not affect development of macrophage-granulocyte or erythroid lineages, it severely disrupts lymphopoiesis. Transplantation of $\mathrm{Bcll1}_{1} \mathrm{a}^{-/-}$fetal liver cells into irradiated mice results in $\mathrm{T}$-cell leukemia and almost no donor-derived B-cell production. Conditional Bcl11a targeting in the adult also revealed a crucial role in controlling lymphopoiesis (Yu et al. 2012). Thus, an additional challenge relates to establishing efficacy in erythroid cells, while minimizing potential deleterious actions on immune cell function. However, with modern approaches to drug design, potential opportunities for developing BCL11A targeting strategies indirectly through upstream factors, and fundamental pharmacological development, there is no reason to believe that these challenges will be insurmountable. Given the emerging rich flavor of the core GATA-1 regulatory function, in conjunction with additional regulatory layers that will almost certainly implicate previously undiscovered mechanisms, rationale is high for continuing to drill deeply into these mechanisms. This type of work will undoubtedly yield further payoffs vis-a-vis innovative mechanistic insights, attractive therapeutic targets that lead to efficacious therapies for hemoglobinopathies, and serendipitous dis- coveries that advance science and medicine in disparate fields.

\section{ACKNOWLEDGMENTS}

We acknowledge funding from National Institutes of Health (NIH) DK50107. A.W.D. was supported by NIH T32 GM081061. N.J.P. was supported by an American Heart Association Predoctoral Fellowship.

\section{REFERENCES}

* Reference is also in this collection.

Anguita E, Hughes J, Heyworth C, Blobel GA, Wood WG, Higgs DR. 2004. Globin gene activation during haemopoiesis is driven by protein complexes nucleated by GATA-1 and GATA-2. EMBO J 23: 2841-2852.

Arceci RJ, King AA, Simon MC, Orkin SH, Wilson DB. 1993. Mouse GATA-4: A retinoic acid-inducible GATAbinding transcription factor expressed in endodermally derived tissues and heart. Mol Cell Biol 13: $2235-$ 2246.

Atweh GF, Schechter AN. 2001. Pharmacologic induction of fetal hemoglobin: Raising the therapeutic bar in sickle cell disease. Curr Opin Hematol 8: 123-130.

Bank A. 2006. Regulation of human fetal hemoglobin: New players, new complexities. Blood 107: 435-443.

Bartunek P, Kralova J, Blendinger G, Dvorak M, Zenke M. 2003. GATA-1 and c-myb crosstalk during red blood cell differentiation through GATA-1 binding sites in the cmyb promoter. Oncogene 22: 1927-1935.

Basu P, Morris PE, Haar JL, Wani MA, Lingrel JB, Gaensler KM, Lloyd JA. 2005. KLF2 is essential for primitive erythropoiesis and regulates the human and murine embryonic $\beta$-like globin genes in vivo. Blood 106: 25662571.

Bender MA, Bulger M, Close J, Groudine M. 2000a. $\beta$-globin gene switching and DNaseI sensitivity of the endogenous $\beta$-globin locus in mice do not require the locus control region. Mol Cell 5: 387-393.

Bender MA, Mehaffey MG, Telling A, Hug B, Ley TJ, Groudine M, Fiering S. 2000b. Independent formation of DnaseI hypersensitive sites in the murine $\beta$-globin locus control region. Blood 95: 3600-3604.

Bender MA, Roach JN, Halow J, Close J, Alami R, Bouhassira EE, Groudine M, Fiering SN. 2001. Targeted deletion of $5^{\prime} \mathrm{HS} 1$ and $5^{\prime} \mathrm{HS} 4$ of the $\beta$-globin locus control region reveals additive activity of the DNaseI hypersensitive sites. Blood 98: 2022-2027.

Blau CA, Stamatoyannopoulos G. 1994. Hemoglobin switching and its clinical implications. Curr Opin Hematol 1: 136- 142 .

Blobel GA, Nakajima T, Eckner R, Montminy M, Orkin SH. 1998. CREB-binding protein cooperates with transcription factor GATA-1 and is required for erythroid differentiation. Proc Natl Acad Sci 95: 2061-2066. 
K.R. Katsumura et al.

Borg J, Papadopoulos P, Georgitsi M, Gutierrez L, Grech G, Fanis P, Phylactides M, Verkerk AJ, van der Spek PJ, Scerri CA, et al. 2010. Haploinsufficiency for the erythroid transcription factor KLF1 causes hereditary persistence of fetal hemoglobin. Nat Genet 42: 801-805.

Bottardi S, Ross J, Bourgoin V, Fotouhi-Ardakani N, Affar el B, Trudel M, Milot E. 2009. Ikaros and GATA-1 combinatorial effect is required for silencing of human $\gamma$ globin genes. Mol Cell Biol 29: 1526-1537.

Bresnick EH, Martowicz ML, Pal S, Johnson KD. 2005. Developmental control via GATA factor interplay at chromatin domains. J Cell Physiol 205: 1-9.

Bresnick EH, Johnson KD, Kim SI, Im H. 2006. Establishment and regulation of chromatin domains: Mechanistic insights from studies of hemoglobin synthesis. Prog Nucleic Acid Res Mol Biol 81: 435-471.

Bresnick EH, Lee HY, Fujiwara T, Johnson KD, Keles S. 2010. GATA switches as developmental drivers. J Biol Chem 285: 31087-31093.

Bresnick EH, Katsumura KR, Lee HY, Johnson KD, Perkins AS. 2012. Master regulatory GATA transcription factors: Mechanistic principles and emerging links to hematologic malignancies. Nucleic Acids Res 40: 5819-5831.

Bultman SJ, Gebuhr TC, Magnuson T. 2005. A Brg1 mutation that uncouples ATPase activity from chromatin remodeling reveals an essential role for SWI/SNF complexes in $\beta$-globin expression and erythroid development. Genes Dev 19: 2849-2861.

Bungert J, Dave U, Lim KC, Lieuw KH, Shavit JA, Liu Q, Engel JD. 1995. Synergistic regulation of human $\beta$-globin gene switching by locus control region elements HS3 and HS4. Genes Dev 9: 3083-3096.

Bungert J, Tanimoto K, Patel S, Liu Q, Fear M, Engel JD. 1999. Hypersensitive site 2 specifies a unique function within the human $\beta$-globin locus control region to stimulate globin gene transcription. Mol Cell Biol 19: $3062-$ 3072.

Bunn HF. 1999. Induction of fetal hemoglobin in sickle cell disease. Blood 93: 1787-1789.

Campbell AD, Cui S, Shi L, Urbonya R, Mathias A, Bradley K, Bonsu KO, Douglas RR, Halford B, Schmidt L, et al. 2011. Forced TR2/TR4 expression in sickle cell disease mice confers enhanced fetal hemoglobin synthesis and alleviated disease phenotypes. Proc Natl Acad Sci 108: $18808-18813$.

Cantor AB, Katz SG, Orkin SH. 2002. Distinct domains of the GATA-1 cofactor FOG-1 differentially influence erythroid versus megakaryocytic maturation. Mol Cell Biol 22: $4268-4279$.

Cantor AB, Iwasaki H, Arinobu Y, Moran TB, Shigematsu H, Sullivan MR, Akashi K, Orkin SH. 2008. Antagonism of FOG-1 and GATA factors in fate choice for the mast cell lineage. J Exp Med 205: 611-624.

Caterina JJ, Ciavatta DJ, Donze D, Behringer RR, Townes TM. 1994. Multiple elements in human $\beta$-globin locus control region $5^{\prime}$ HS 2 are involved in enhancer activity and position-independent, transgene expression. Nucleic Acids Res 22: 1006-1011.

Cheng Y, Wu W, Kumar SA, Yu D, Deng W, Tripic T, King DC, Chen KB, Zhang Y, Drautz D, et al. 2009. Erythroid GATA1 function revealed by genome-wide analysis of transcription factor occupancy, histone modifications, and mRNA expression. Genome Res 19: 2172-2184.

Chlon TM, Dore LC, Crispino JD. 2012. Cofactor-mediated restriction of GATA-1 chromatin occupancy coordinates lineage-specific gene expression. Mol Cell 47: 608-621.

Collavin L, Gostissa M, Avolio F, Secco P, Ronchi A, Santoro C, Del Sal G. 2004. Modification of the erythroid transcription factor GATA-1 by SUMO-1. Proc Natl Acad Sci 101: 8870-8875.

Conaway RC, Sato S, Tomomori-Sato C, Yao T, Conaway JW. 2005. The mammalian mediator complex and its role in transcriptional regulation. Trends Biochem Sci 30: 250255.

Costa FC, Fedosyuk H, Chazelle AM, Neades RY, Peterson KR. 2012. Mi2 $\beta$ is required for $\gamma$-globin gene silencing: Temporal assembly of a GATA-1-FOG-1-Mi2 repressor complex in $\beta$-YAC transgenic mice. PLoS Genet 8: e1003155.

Crawford SE, Qi C, Misra P, Stellmach V, Rao MS, Engel JD, Zhu Y, Reddy JK. 2002. Defects of the heart, eye, and megakaryocytes in peroxisome proliferator activator receptor-binding protein (PBP) null embryos implicate GATA family of transcription factors. J Biol Chem 277: 3585-3592.

Crispino JD. 2005. GATA-1 in normal and malignant hematopoiesis. Semin Cell Dev Biol 16: 137-147.

Crispino JD, Lodish MB, MacKay JP, Orkin SH. 1999. Use of altered specificity mutants to probe a specific proteinprotein interaction in differentiation: The GATA-1:FOG complex. Mol Cell 3: 219-228.

Crossley M, Orkin SH. 1994. Phosphorylation of the erythroid transcription factor GATA-1. J Biol Chem 269: 16589-16596.

De Gobbi M, Viprakasit V, Hughes JR, Fisher C, Buckle VJ, Ayyub H, Gibbons RJ, Vernimmen D, Yoshinaga Y, de Jong P, et al. 2006. A regulatory SNP causes a human genetic disease by creating a new transcriptional promoter. Science 312: 1215-1217.

De Gobbi M, Anguita E, Hughes J, Sloane-Stanley JA, Sharpe JA, Koch CM, Dunham I, Gibbons RJ, Wood WG, Higgs DR. 2007. Tissue-specific histone modification and transcription factor binding in $\alpha$ globin gene expression. Blood 110: 4503-4510.

Dore LC, Chlon TM, Brown CD, White KP, Crispino JD. 2012. Chromatin occupancy analysis reveals genomewide GATA factor switching during hematopoiesis. Blood 119: 3724-3733.

Dorfman DM, Wilson DB, Bruns GA, Orkin SH. 1992. Human transcription factor GATA-2. Evidence for regulation of preproendothelin-1 gene expression in endothelial cells. J Biol Chem 267: 1279-1285.

Driscoll MC, Dobkin CS, Alter BP. 1989. $\gamma \delta \beta$-Thalassemia due to a de novo mutation deleting the $5^{\prime} \beta$-globin gene activation-region hypersensitive sites. Proc Natl Acad Sci 86: $7470-7474$.

Drissen R, Palstra RJ, Gillemans N, Splinter E, Grosveld F, Philipsen S, de Laat W. 2004. The active spatial organization of the $\beta$-globin locus requires the transcription factor EKLF. Genes Dev 18: 2485-2490.

Ellis J, Talbot D, Dillon N, Grosveld F. 1993. Synthetic human $\beta$-globin $5^{\prime} H S 2$ constructs function as locus control 
regions only in multicopy transgene concatamers. $E M B O$ J 12: $127-134$

Ellis J, Tan-Un KC, Harper A, Michalovich D, Yannoutsos N, Philipsen S, Grosveld F. 1996. A dominant chromatinopening activity in $5^{\prime}$ hypersensitive site 3 of the human $\beta$-globin locus control region. EMBO J 15: 562-568.

Epner E, Reik A, Cimbora D, Telling A, Bender MA, Fiering S, Enver T, Martin DI, Kennedy M, Keller G, et al. 1998. The $\beta$-globin LCR is not necessary for an open chromatin structure or developmentally regulated transcription of the native mouse $\beta$-globin locus. Mol Cell 2: 447-455.

Evans T, Felsenfeld G. 1989. The erythroid-specific transcription factor Eryf1: A new finger protein. Cell 58: 877-885.

Evans T, Reitman M, Felsenfeld G. 1988. An erythrocytespecific DNA-binding factor recognizes a regulatory sequence common to all chicken globin genes. Proc Natl Acad Sci 85: 5976-5980.

Evans T, Felsenfeld G, Reitman M. 1990. Control of globin gene transcription. Annu Rev Cell Biol 6: 95-124.

Fibach E, Burke KP, Schechter AN, Noguchi CT, Rodgers GP. 1993. Hydroxyurea increases fetal hemoglobin in cultured erythroid cells derived from normal individuals and patients with sickle cell anemia or $\beta$-thalassemia. Blood 81: 1630-1635.

Fiering S, Epner E, Robinson K, Zhuang Y, Telling A, Hu M Martin DI, Enver T, Ley TJ, Groudine M. 1995. Targeted deletion of $5^{\prime} \mathrm{HS} 2$ of the murine $\beta$-globin LCR reveals that it is not essential for proper regulation of the $\beta$ globin locus. Genes Dev 9: 2203-2213.

Filipe A, Li Q, Deveaux S, Godin I, Romeo P-H, Stamatopannopoulos G, Mignotte V. 1999. Regulation of embryonic/fetal globin genes by nuclear hormone receptors: A novel perspective on hemoglobin switching. EMBO J 18: 687-697.

Forrester WC, Thompson C, Elder JT, Groudine M. 1986. A developmentally stable chromatin structure in the human $\beta$-globin locus. Proc Natl Acad Sci 83: 1359-1363.

Forrester WC, Takegawa S, Papayannopoulou T, Stamatoyannopoulos G, Groudine M. 1987. Evidence for a locus activation region: The formation of developmentally stable hypersensitive sites in globin-expressing hybrids. Nucleic Acids Res 15: 10159-10177.

Forrester WC, Epner E, Driscoll MC, Enver T, Brice M, Papayannopoulou T, Groudine M. 1990. A deletion of the human $\beta$-globin locus activation region causes a major alteration in chromatin structure and replication across the entire $\beta$-globin locus. Genes Dev 4: 1637-1649.

Fox AH, Liew C, Holmes M, Kowalski K, MacKay JP, Crossley M. 1999. Transcriptional cofactors of the FOG family interact with GATA proteins by means of multiple zinc fingers. EMBO J 18: 2812-2822.

Fucharoen S, Siritanaratkul N, Winichagoon P, Chowthaworn J, Siriboon W, Muangsup W, Chaicharoen S, Poolsup N, Chindavijak B, Pootrakul P, et al. 1996. Hydroxyurea increases hemoglobin $\mathrm{F}$ levels and improves the effectiveness of erythropoiesis in $\beta$-thalassemia/hemoglobin E disease. Blood 87: 887-892.

Fujiwara Y, Browne CP, Cunniff K, Goff SC, Orkin SH. 1996. Arrested development of embryonic red cell precursors in
Mechanisms Underlying Hemoglobin Synthesis

mouse embryos lacking transcription factor GATA-1. Proc Natl Acad Sci 93: 12355-12358.

Fujiwara T, O'Geen H, Keles S, Blahnik K, Linnemann AK, Kang YA, Choi K, Farnham PJ, Bresnick EH. 2009. Discovering hematopoietic mechanisms through genomewide analysis of GATA factor chromatin occupancy. Mol Cell 36: 667-681.

Funnell AP, Norton LJ, Mak KS, Burdach J, Artuz CM, Twine NA, Wilkins MR, Power CA, Hung TT, Perdomo J, et al. 2012. The CACCC-binding protein KLF3/BKLF represses a subset of KLF1/EKLF target genes and is required for proper erythroid maturation in vivo. Mol Cell Biol 32: 3281-3292.

Gamsjaeger R, Liew CK, Loughlin FE, Crossley M, Mackay JP. 2007. Sticky fingers: Zinc-fingers as proteinrecognition motifs. Trends Biochem Sci 32: 63-70.

Gao Z, Huang Z, Olivey HE, Gurbuxani S, Crispino JD, Svensson EC. 2010. FOG-1-mediated recruitment of $\mathrm{NuRD}$ is required for cell lineage re-enforcement during haematopoiesis. EMBO J 29: 457-468.

Garriga-Canut M, Orkin SH. 2004. Transforming acidic coiled-coil protein 3 (TACC3) controls friend of GATA1 (FOG-1) subcellular localization and regulates the association between GATA-1 and FOG-1 during hematopoiesis. J Biol Chem 279: 23597-23605.

Goodwin AJ, McInerney JM, Glander MA, Pomerantz O, Lowrey CH. 2001. In vivo formation of a human $\beta$-globin locus control region core element requires binding sites for multiple factors including GATA-1, NF-E2, erythroid Krüppel-like factor, and Sp1. J Biol Chem 276: 2688326892.

Grass JA, Boyer ME, Pal S, Wu J, Weiss MJ, Bresnick EH. 2003. GATA-1-dependent transcriptional repression of GATA-2 via disruption of positive autoregulation and domain-wide chromatin remodeling. Proc Natl Acad Sci 100: $8811-8816$.

Grass JA, Jing H, Kim SI, Martowicz ML, Pal S, Blobel GA, Bresnick EH. 2006. Distinct functions of dispersed GATA factor complexes at an endogenous gene locus. $\mathrm{Mol}$ Cell Biol 26: 7056-7067.

Gregory GD, Miccio A, Bersenev A, Wang Y, Hong W, Zhang Z, Poncz M, Tong W, Blobel GA. 2010. FOG1 requires $\mathrm{NuRD}$ to promote hematopoiesis and maintain lineage fidelity within the megakaryocytic-erythroid compartment. Blood 115: 2156-2166.

Grosveld F, van Assendelft GB, Greaves DR, Kollias G. 1987. Position-independent high-level expression of the human $\beta$-globin gene in trangsenic mice. Cell 51: 975-985.

* Hardison RC. 2012. Evolution of hemoglobin and its genes. Cold Spring Harb Perspect Med 2: a011627.

Harju-Baker S, Costa FC, Fedosyuk H, Neades R, Peterson KR. 2008. Silencing of ${ }^{\mathrm{A}} \gamma$-globin gene expression during adult definitive erythropoiesis mediated by GATA-1-FOG-1-Mi2 complex binding at the -566 GATA site. Mol Cell Biol 28: 3101-3113.

Hatton CS, Wilkie AO, Drysdale HC, Wood WG Vickers MA, Sharpe J, Ayyub H, Pretorius IM, Buckle VJ, Higgs DR. 1990. $\alpha$-Thalassemia caused by a large $(62 \mathrm{~kb})$ deletion upstream of the human $\alpha$ globin gene cluster. Blood 76: 221-227.

* Higgs DR. 2013. The molecular basis of $\alpha$-thalassemia. Cold Spring Harb Perspect Med 3: .a011718. 
K.R. Katsumura et al.

Hirasawa R, Shimuzu R, Takahashi S, Osawa M, Takayanagi S, Kato Y, Onodera M, Minegishi N, Yamamoto M, Fukao K, et al. 2002. Essential and instructive roles of GATA factors in eosinophil development. J Exp Med 195: $1379-1386$

Ho IC, Vorhees P, Marin N, Oakley BK, Tsai SF, Orkin SH, Leiden JM. 1991. Human GATA-3: A lineage-restricted transcription factor that regulates the expression of the T cell receptor $\alpha$ gene. EMBO J 10: 1187-1192.

Holmes M, Turner J, Fox A, Chisholm O, Crossley M, Chong B. 1999. hFOG-2, a novel zinc finger protein, binds the co-repressor mCtBP2 and modulates GATAmediated activation. J Biol Chem 274: 23491-23498.

Hong W, Nakazawa M, Chen YY, Kori R, Vakoc CR, Rakowski C, Blobel GA. 2005. FOG-1 recruits the $\mathrm{NuRD}$ repressor complex to mediate transcriptional repression by GATA-1. EMBO J 24: 2367-2378.

Horak CE, Mahajan MC, Luscombe NM, Gerstein M, Weissman SM, Snyder M. 2002. GATA-1 binding sites mapped in the $\beta$-globin locus using mammalian chIpchip analysis. Proc Natl Acad Sci 99: 2924-2929.

Huang Z, Dore LC, Li Z, Orkin SH, Feng G, Lin S, Crispino JD. 2009. GATA-2 reinforces megakaryocyte development in the absence of GATA-1. Mol Cell Biol 29: 5168-5180.

Hug BA, Wesselschmidt RL, Fiering S, Bender MA, Epner E, Groudine M, Ley TJ. 1996. Analysis of mice containing a targeted deletion of $\beta$-globin locus control region $5^{\prime}$ hypersensitive site 3. Mol Cell Biol 16: 2906-2912.

Humbles AA, Lloyd CM, McMillan SJ, Friend DS, Xanthou G, McKenna EE, Ghiran S, Gerard NP, Yu C, Orkin SH, et al. 2004. A critical role for eosinophils in allergic airways remodeling. Science 305: 1776-1779.

Hung HL, Lau J, Kim AY, Weiss MJ, Blobel GA. 1999. CREBbinding protein acetylates hematopoietic transcription factor GATA-1 at functionally important sites. Mol Cell Biol 19: 3496-3505.

Im H, Grass JA, Johnson KD, Kim SI, Boyer ME, Imbalzano AN, Bieker JJ, Bresnick EH. 2005. Chromatin domain activation via GATA-1 utilization of a small subset of dispersed GATA motifs within a broad chromosomal region. Proc Natl Acad Sci 102: 17065-17070.

Ito $\mathrm{E}$, Toki T, Ishihara $\mathrm{H}$, Ohtani $\mathrm{H}, \mathrm{Gu} \mathrm{L}$, Yokoyama $\mathrm{M}$, Engel JD, Yamamoto M. 1993. Erythroid transcription factor GATA-1 is abundantly transcribed in mouse testis. Nature 362: 466-468.

Jane SM, Nienhuis AW, Cunningham JM. 1995. Hemoglobin switching in man and chicken is mediated by a heteromeric complex between the ubiquitous transcription factor $\mathrm{CP} 2$ and a developmentally specific protein. EMBO J 14: 97-105.

Johnson KD, Christensen HM, Zhao B, Bresnick EH. 2001. Distinct mechanisms control RNA polymerase II recruitment to a tissue-specific locus control region and a downstream promoter. Mol Cell 8: 465-471.

Johnson KD, Grass JD, Boyer ME, Kiekhaefer CM, Blobel GA, Weiss MJ, Bresnick EH. 2002. Cooperative activities of hematopoietic regulators recruit RNA polymerase II to a tissue-specific chromatin domain. Proc Natl Acad Sci 99: 11760-11765.

Johnson KD, Grass JA, Park C, Im H, Choi K, Bresnick EH. 2003. Highly restricted localization of RNA polymerase II within a locus control region of a tissue-specific chromatin domain. Mol Cell Biol 23: 6484-6493.

Johnson KD, Kim SI, Bresnick EH. 2006. Differential sensitivities of transcription factor target genes underlie cell type-specific gene expression profiles. Proc Natl Acad Sci 103: 15939-15944.

Johnson KD, Boyer ME, Kang JA, Wickrema A, Cantor AB, Bresnick EH. 2007. Friend of GATA-1-independent transcriptional repression: A novel mode of GATA-1 function. Blood 109: 5230-5233.

Johnson KD, Hsu AP, Ryu MJ, Wang J, Gao X, Boyer ME, Liu Y, Lee Y, Calvo KR, Keles S, et al. 2012. Cis-element mutated in GATA2-dependent immunodeficiency governs hematopoiesis and vascular integrity. J Clin Invest 122: 3692-3704.

Kadri Z, Maouche-Chretien L, Rooke HM, Orkin SH, Romeo PH, Mayeux P, Leboulch P, Chretien S. 2005. Phosphatidylinositol 3-kinase/Akt induced by erythropoietin renders the erythroid differentiation factor GATA-1 competent for TIMP-1 gene transactivation. Mol Cell Biol 25: 7412-7422.

Kang YA, Sanalkumar R, O'Geen H, Linnemann AK, Chang CJ, Bouhassira EE, Farnham PJ, Keles S, Bresnick EH. 2012. Autophagy driven by a master regulator of hematopoiesis. Mol Cell Biol 32: 226-239.

Katz SG, Cantor AB, Orkin SH. 2002. Interaction between FOG- 1 and the corepressor $\mathrm{C}$-terminal binding protein is dispensable for normal erythropoiesis in vivo. Mol Cell Biol 22: 3121-3128.

Kelley C, Blumberg H, Zon LI, Evans T. 1993. GATA-4 is a novel transcription factor expressed in endocardium of the developing heart. Development 118: 817-827.

Khanna R, Chang SH, Andrabi S, Azam M, Kim A, Rivera A, Brugnara C, Low PS, Liu SC, Chishti AH. 2002. Headpiece domain of dematin is required for the stability of the erythrocyte membrane. Proc Natl Acad Sci 99: 6637-6642.

Kiekhaefer CM, Grass JA, Johnson KD, Boyer ME, Bresnick EH. 2002. Hematopoietic-specific activators establish an overlapping pattern of histone acetylation and methylation within a mammalian chromatin domain. Proc Natl Acad Sci 99: 14309-14314.

Kim SI, Bresnick EH. 2007. Transcriptional control of erythropoiesis: Emerging mechanisms and principles. Oncogene 26: 6777-6794.

Kim SI, Bultman SJ, Jing H, Blobel GA, Bresnick EH. 2007. Dissecting molecular steps in chromatin domain activation during hematopoietic differentiation. Mol Cell Biol 27: 4551-4565.

Kim SI, Bresnick EH, Bultman SJ. 2009a. BRG1 directly regulates nucleosome structure and chromatin looping of the $\alpha$ globin locus to activate transcription. Nucleic Acids Res 37: 6019-6027.

Kim SI, Bultman SJ, Kiefer CM, Dean A, Bresnick EH. 2009b. BRG1 requirement for long-range interaction of a locus control region with a downstream promoter. Proc Natl Acad Sci 106: 2259-2264.

Ko LJ, Engel JD. 1993. DNA-binding specificities of the GATA transcription factor family. Mol Cell Biol 13: 4011-4022. 
Kornberg RD. 2005. Mediator and the mechanism of tran scriptional activation. Trends Biochem Sci 30: 235-239.

Kuo CT, Morrisey EE, Anandappa R, Sigrist K, Lu MM, Parmacek MS, Soudais C, Leiden JM. 1997. GATA4 transcription factor is required for ventral morphogenesis and heart tube formation. Genes Dev 11: 1048-1060.

Kutlar A, Ataga K, Reid M, Vichinsky EP, Neumayr L, BlairBritt L, Labotka R, Glass J, Keefer JR, Wargin WA, et al. 2012. A phase $1 / 2$ trial of HQK-1001, an oral fetal globin inducer, in sickle cell disease. Am J Hematol 87: 10171021.

Lamonica JM, Vakoc CR, Blobel GA. 2006. Acetylation of GATA-1 is required for chromatin occupancy. Blood 108: 3736-3738.

Lamonica JM, Deng W, Kadauke S, Campbell AE, Gamsjaeger R, Wang H, Cheng Y, Billin AN, Hardison RC, Mackay JP, et al. 2011. Bromodomain protein Brd3 associates with acetylated GATA1 to promote its chromatin occupancy at erythroid target genes. Proc Natl Acad Sci 108: E159-E168.

Lavelle D, Saunthararajah Y, Desimone J. 2008. Comment on DNA methylation and mechanism of action of 5-azacytidine. Blood 111: 2485.

Lee ME, Temizer DH, Clifford JA, Quertermous T. 1991. Cloning of the GATA binding protein that regulates endothelin-1 gene expression in endothelial cells. J Biol Chem 266: 16188-16192.

Lee HY, Johnson KD, Fujiwara T, Boyer ME, Kim SI, Bresnick EH. 2009. Controlling hematopoiesis through sumoylation-dependent regulation of a GATA factor. $\mathrm{Mol}$ Cell 36: 984-995.

Lee HY, Johnson KD, Boyer ME, Bresnick EH. 2011. Relocalizing genetic loci into specific subnuclear neighborhoods. J Biol Chem 286: 18834-18844.

Letting DL, Rakowski C, Weiss MJ, Blobel GA. 2003. Formation of a tissue-specific histone acetylation pattern by the hematopoietic transcription factor GATA-1. Mol Cell Biol 23: 1334-1340.

Letting DL, Chen YY, Rakowski C, Reedy S, Blobel GA. 2004. Context-dependent regulation of GATA-1 by friend of GATA-1. Proc Natl Acad Sci 101: 476-481.

* Lettre G. 2012. The search for genetic modifiers of disease severity in the $\beta$-hemoglobinopathies. Cold Spring Harb Perspect Med 2: a015032.

Lettre G, Sankaran VG, Bezerra MA, Araujo AS, Uda M, Sanna S, Cao A, Schlessinger D, Costa FF, Hirschhorn JN, et al. 2008. DNA polymorphisms at the BCL11A, HBS1LMYB, and $\beta$-globin loci associate with fetal hemoglobin levels and pain crises in sickle cell disease. Proc Natl Acad Sci 105: 11869-11874.

Liew CK, Simpson RJY, Kwan AHY, Crofts LA, Loughlin FE, Matthews JM, Crossley M, MacKay JP. 2005. Zinc fingers as protein recognition motifs: Structural basis for the GATA-1/Friend of GATA interaction. Proc Natl Acad Sci 102: $583-588$.

Lim KC, Hosoya T, Brandt W, Ku CJ, Hosoya-Ohmura S, Camper SA, Yamamoto M, Engel JD. 2012. Conditional Gata2 inactivation results in HSC loss and lymphatic mispatterning. J Clin Invest 122: 3705-3717.

Linnemann AK, O'Geen H, Keles S, Farnham PJ, Bresnick EH. 2011. Genetic framework for GATA factor
Mechanisms Underlying Hemoglobin Synthesis

function in vascular biology. Proc Natl Acad Sci 108: 13641-13646.

Liu P, Keller JR, Ortiz M, Tessarollo L, Rachel RA, Nakamura T, Jenkins NA, Copeland NG. 2003. Bcl11a is essential for normal lymphoid development. Nat Immunol 4: 525-532.

Lopez RA, Schoetz S, DeAngelis K, O’Neill D, Bank A. 2002. Multiple hematopoietic defects and delayed globin switching in Ikaros null mice. Proc Natl Acad Sci 99: 602-607.

Lu JR, McKinsey TA, Xu H, Wang DZ, Richardson JA, Olson EN. 1999. FOG-2, a heart- and brain-enriched cofactor for GATA transcription factors. Mol Cell Biol 19: $4495-4502$.

Lugus JJ, Chung YS, Mills JC, Kim SI, Grass JA, Kyba M, Doherty JM, Bresnick EH, Choi K. 2007. GATA2 functions at multiple steps in hemangioblast development and differentiation. Development 134: 393-405.

Mabaera R, Greene MR, Richardson CA, Conine SJ, Kozul CD, Lowrey CH. 2008. Neither DNA hypomethylation nor changes in the kinetics of erythroid differentiation explain 5-azacytidine's ability to induce human fetal hemoglobin. Blood 111: 411-420.

Macari ER, Lowrey CH. 2011. Induction of human fetal hemoglobin via the NRF2 antioxidant response signaling pathway. Blood 117: 5987-5997.

Macari ER, Schaeffer EK, West RJ, Lowrey CH. 2012. Simvastatin and t-butylhydroquinone suppress KLF1 and BCL11A gene expression and additively increase fetal hemoglobin in primary human erythroid cells. Blood 121: $830-839$.

Martin DI, Orkin SH. 1990. Transcriptional activation and DNA binding by the erythroid factor GF-1/NF-E1/Eryf 1. Genes Dev 4: 1886-1898.

Martowicz ML, Grass JA, Boyer ME, Guend H, Bresnick EH. 2005. Dynamic GATA factor interplay at a multicomponent regulatory region of the GATA-2 locus. J Biol Chem 280: $1724-1732$.

Menzel S, Garner C, Gut I, Matsuda F, Yamaguchi M, Heath S, Foglio M, Zelenika D, Boland A, Rooks H, et al. 2007a. A QTL influencing F cell production maps to a gene encoding a zinc-finger protein on chromosome 2p15. Nat Genet 39: 1197-1199.

Menzel S, Jiang J, Silver N, Gallagher J, Cunningham J, Surdulescu G, Lathrop M, Farrall M, Spector TD, Thein SL. 2007b. The HBS1L-MYB intergenic region on chromosome 6q23.3 influences erythrocyte, platelet, and monocyte counts in humans. Blood 110: 3624-3626.

Merika M, Orkin SH. 1993. DNA-binding specificity of GATA family transcription factors. Mol Cell Biol 13: 3999-4010.

Miccio A, Blobel GA. 2010. Role of the GATA-1/FOG-1/ $\mathrm{NuRD}$ pathway in the expression of human $\beta$-like globin genes. Mol Cell Biol 30: 3460-3470.

Miccio A, Wang Y, Hong W, Gregory GD, Wang H, Yu X, Choi JK, Shelat S, Tong W, Poncz M, et al. 2010. NuRD mediates activating and repressive functions of GATA-1 and FOG-1 during blood development. EMBO J 29: $442-456$.

Migliaccio AR, Rana RA, Sanchez M, Lorenzini R, Centurione L, Bianchi L, Vannucchi AM, Migliaccio G, 
K.R. Katsumura et al.

Orkin SH. 2003. GATA-1 as a regulator of mast cell differentiation revealed by the phenotype of the GATA- $1^{\text {low }}$ mouse mutant. J Exp Med 197: 281-296.

Miller IJ, Bieker JJ. 1993. A novel, erythroid cell-specific murine transcription factor that binds to the CACCC element and is related to the Krüppel family of nuclear proteins. Mol Cell Biol 13: 2776-2786.

Mohseni M, Chishti AH. 2008. The headpiece domain of dematin regulates cell shape, motility, and wound healing by modulating RhoA activation. Mol Cell Biol 28: $4712-4718$.

Molkentin JD, Lin Q, Duncan SA, Olson EN. 1997. Requirement of the transcription factor GATA4 for heart tube formation and ventral morphogenesis. Genes Dev 11: 1061-1072.

Morrisey EE, Ip HS, Lu MM, Parmacek MS. 1996. GATA-6: A zinc finger transcription factor that is expressed in multiple cell lineages derived from lateral mesoderm. Dev Biol 177: 309-322.

Morrisey EE, Ip HS, Tang Z, Lu MM, Parmacek MS. 1997. GATA-5: A transcriptional activator expressed in a novel temporally and spatially-restricted pattern during embryonic development. Dev Biol 183: 21-36.

Navas PA, Peterson KR, Li Q, Skarpidi E, Rohde A, Shaw SE, Clegg CH, Asano H, Stamatoyannopoulos G. 1998. Developmental specificity of the interaction between the locus control region and embryonic or fetal globin genes in transgenic mice with an HS3 core deletion. Mol Cell Biol 18: 4188-4196.

Navas PA, Peterson KR, Li Q, McArthur M, Stamatoyannopoulos G. 2001. The 5'HS4 core element of the human $\beta$-globin locus control region is required for high-level globin gene expression in definitive but not in primitive erythropoiesis. J Mol Biol 312: 17-26.

Nichols KE, Crispino JD, Poncz M, White JG, Orkin SH, Maris JM, Weiss MJ. 2000. Familial dyserythropoietic anaemia and thrombocytopenia due to an inherited mutation in GATA1. Nat Genet 24: 266-270.

* Nienhuis AW, Nathan DG. 2012. Pathophysiology and clinical manifestations of the $\beta$-thalassemias. Cold Spring Harb Perspect Med 2: a011726.

Orkin SH. 1990. Globin gene regulation and switching: Circa 1990. Cell 63: 665-672.

Orkin SH, Higgs DR. 2010. Medicine. Sickle cell disease at 100 years. Science 329: 291-292.

Pace BS, Qian XH, Sangerman J, Ofori-Acquah SF, Baliga BS, Han J, Critz SD. 2003. p38 MAP kinase activation mediates $\gamma$-globin gene induction in erythroid progenitors. Exp Hematol 31: 1089-1096.

Pal S, Cantor AB, Johnson KD, Moran TB, Boyer ME, Orkin SH, Bresnick EH. 2004. Coregulator-dependent facilitation of chromatin occupancy by GATA-1. Proc Natl Acad Sci 101: 980-985.

Pawlik KM, Townes TM. 1995. Autonomous, erythroid-specific DNase I hypersensitive site formed by human $\beta$ globin locus control region (LCR) $5^{\prime}$ HS 2 in transgenic mice. Dev Biol 169: 728-732.

Perkins AC, Sharpe AH, Orkin SH. 1995. Lethal $\beta$-thalassaemia in mice lacking the erythroid CACCC-transcription factor EKLF. Nature 375: 318-322.
Persons DA, Allay JA, Allay ER, Ashmun RA, Orlic D, Jane SM, Cunningham JM, Nienhuis AW. 1999. Enforced expression of the GATA-2 transcription factor blocks normal hematopoiesis. Blood 93: 488-499.

Peterson KR, Clegg CH, Navas PA, Norton EJ, Kimbrough TG, Stamatoyannopoulos G. 1996. Effect of deletion of $5^{\prime} \mathrm{HS} 3$ or $5^{\prime} \mathrm{HS} 2$ of the human $\beta$-globin locus control region on the developmental regulation of globin gene expression in $\beta$-globin locus yeast artificial chromosome transgenic mice. Proc Natl Acad Sci 93: 6605-6609.

Pevny L, Simon MC, Robertson E, Klein WH, Tsai SF, D'Agati V, Orkin SH, Costantini F. 1991. Erythroid differentiation in chimaeric mice blocked by a targeted mutation in the gene for transcription factor GATA-1. Nature 349: $257-260$.

Pevny L, Lin CS, D’Agati V, Simon MC, Orkin SH, Costantini F. 1995. Development of hematopoietic cells lacking transcription factor GATA-1. Development 121: $163-172$.

Philipsen S, Talbot D, Fraser P, Grosveld F. 1990. The $\beta$ globin dominant control region: Hypersensitive site 2 . EMBO J 9: 2159-2167.

Philipsen S, Pruzina S, Grosveld F. 1993. The minimal requirements for activity in transgenic mice of hypersensitive site 3 of the $\beta$ globin locus control region. Embo J 12: 1077-1085.

Pomerantz O, Goodwin AJ, Joyce T, Lowrey CH. 1998. Conserved elements containing NF-E2 and tandem GATA binding sites are required for erythroid-specific chromatin structure reorganization within the human $\beta$-globin locus control region. Nucleic Acids Res 26: 5684-5691.

Pope NJ, Bresnick EH. 2010. Differential coregulator requirements for function of the hematopoietic transcription factor GATA-1 at endogenous loci. Nucleic Acids Res 38: $2190-2200$.

Pruzina S, Hanscombe O, Whyatt D, Grosveld F, Philipsen S. 1991. Hypersensitive site 4 of the human $\beta$ globin locus control region. Nucleic Acids Res 19: 1413-1419.

Pruzina S, Antoniou M, Hurst J, Grosveld F, Philipsen S. 1994. Transcriptional activation by hypersensitive site three of the human $\beta$-globin locus control region in murine erythroleukemia cells. Biochim Biophys Acta 1219: 351-360.

Raich N, Clegg CH, Grofti J, Romeo PH, Stamatoyannopoulos G. 1995. GATA1 and YY1 are developmental repressors of the human $\varepsilon$-globin gene. $E M B O J$ 14: 801-809.

Rana AP, Ruff P, Maalouf GJ, Speicher DW, Chishti AH. 1993. Cloning of human erythroid dematin reveals another member of the villin family. Proc Natl Acad Sci 90: 6651-6655.

Reik A, Telling A, Zitnik G, Cimbora D, Epner E, Groudine M. 1998. The locus control region is necessary for gene expression in the human $\beta$-globin locus but not the maintenance of an open chromatin structure in erythroid cells. Mol Cell Biol 18: 5992-6000.

Rodgers GP, Dover GJ, Noguchi CT, Schechter AN, Nienhuis AW. 1989. Induction of fetal hemoglobin in sickle cell patients by hydroxyurea: The N.I.H. experience. Prog Clin Biol Res 316B: 281-293.

Rodgers GP, Dover GJ, Uyesaka N, Noguchi CT, Schechter AN, Nienhuis AW. 1993. Augmentation by erythropoietin 
of the fetal-hemoglobin response to hydroxyurea in sickle cell disease. N Engl J Med 328: 73-80.

Ross J, Mavoungou L, Bresnick EH, Milot E. 2012. GATA-1 utilizes Ikaros and polycomb repressive complex 2 to suppress Hes1 and to promote erythropoiesis. Mol Cell Biol 32: 3624-3638.

Rupon JW, Wang SZ, Gaensler K, Lloyd J, Ginder GD. 2006. Methyl binding domain protein 2 mediates $\gamma$-globin gene silencing in adult human $\beta$ YAC transgenic mice. Proc Natl Acad Sci 103: 6617-6622.

Rupon JW, Wang SZ, Gnanapragasam M, Labropoulos S, Ginder GD. 2011. MBD2 contributes to developmental silencing of the human $\varepsilon$-globin gene. Blood Cells Mol Dis 46: $212-219$.

Ryan TM, Behringer RR, Martin NC, Townes TM, Palmiter RD, Brinster RL. 1989. A single erythroid-specific DNase I super-hypersensitive site activates high levels of human $\beta$-globin gene expression in transgenic mice. Genes Dev 3: 314-323.

Sangerman J, Lee MS, Yao X, Oteng E, Hsiao CH, Li W, Zein S, Ofori-Acquah SF, Pace BS. 2006. Mechanism for fetal hemoglobin induction by histone deacetylase inhibitors involves $\gamma$-globin activation by CREB1 and ATF-2. Blood 108: 3590-3599.

* Sankaran VG, Orkin SH. 2013. The switch from fetal to adult hemoglobin. Cold Spring Harb Perspect Med 3: a011643.

Sankaran VG, Menne TF, Xu J, Akie TE, Lettre G, Van Handel B, Mikkola HK, Hirschhorn JN, Cantor AB, Orkin SH. 2008. Human fetal hemoglobin expression is regulated by the developmental stage-specific repressor BCL11A. Science 322: 1839-1842.

Sankaran VG, Xu J, Ragoczy T, Ippolito GC, Walkley CR, Maika SD, Fujiwara Y, Ito M, Groudine M, Bender MA, et al. 2009. Developmental and species-divergent globin switching are driven by BCL11A. Nature 460: $1093-$ 1097.

Sankaran VG, Xu J, Orkin SH. 2010a. Advances in the understanding of haemoglobin switching. Br J Haematol 149: $181-194$.

Sankaran VG, Xu J, Orkin SH. 2010b. Transcriptional silencing of fetal hemoglobin by BCL11A. Ann NY Acad Sci 1202: 64-68.

Sankaran VG, Menne TF, Scepanovic D, Vergilio JA, Ji P, Kim J, Thiru P, Orkin SH, Lander ES, Lodish HF. 2011 MicroRNA-15a and -16-1 act via MYB to elevate fetal hemoglobin expression in human trisomy 13. Proc Natl Acad Sci 108: 1519-1524.

Schoenfelder S, Sexton T, Chakalova L, Cope NF, Horton A, Andrews S, Kurukuti S, Mitchell JA, Umlauf D, Dimitrova DS, et al. 2010. Preferential associations between co-regulated genes reveal a transcriptional interactome in erythroid cells. Nat Genet 42: 53-61.

Simon MC, Pevny L, Wiles MV, Keller G, Costantini F, Orkin SH. 1992. Rescue of erythroid development in gene targeted GATA- $1^{-}$mouse embryonic stem cells. Nat Genet 1: 92-98.

Simpson RJ, Yi Lee SH, Bartle N, Sum EY, Visvader JE, Matthews JM, MacKay JP, Crossley M. 2004. A classic zinc finger from friend of GATA mediates an interaction with the coiled-coil of transforming acidic coiled-coil 3. J Biol Chem 279: 39789-39797.
Mechanisms Underlying Hemoglobin Synthesis

Snow JW, Kim J, Currie CR, Xu J, Orkin SH. 2010a. Sumoylation regulates interaction of FOG1 with C-terminalbinding protein (CTBP). J Biol Chem 285: 28064-28075.

Snow JW, Trowbridge JJ, Fujiwara T, Emambokus NE, Grass JA, Orkin SH, Bresnick EH. 2010b. A single cis element maintains repression of the key developmental regulator Gata2. PLoS Genet 6: e1001103.

Snow JW, Trowbridge JJ, Johnson KD, Fujiwara T, Emambokus NE, Grass JA, Orkin SH, Bresnick EH. 2011. Context-dependent function of "GATA" sites in vivo. Blood 117: 4769-4772.

Song SH, Hou C, Dean A. 2007. A positive role for NLI/ Ldb1 in long-range $\beta$-globin locus control region function. Mol Cell 28: 810-822.

Souroullas GP, Salmon JM, Sablitzky F, Curtis DJ, Goodell MA. 2009. Adult hematopoietic stem and progenitor cells require either Lyll or Scl for survival. Cell Stem Cell 4: 180-186.

Sripichai O, Kiefer CM, Bhanu NV, Tanno T, Noh SJ, Goh SH, Russell JE, Rognerud CL, Ou CN, Oneal PA, et al. 2009. Cytokine-mediated increases in fetal hemoglobin are associated with globin gene histone modification and transcription factor reprogramming. Blood 114: 2299-2306.

Stamatoyannopoulos JA, Goodwin A, Joyce T, Lowrey CH. 1995. NF-E2 and GATA binding motifs are required for the formation of DNase I hypersensitive site 4 of the human $\beta$-globin locus control region. EMBO J 14: $106-116$.

Stumpf M, Waskow C, Krotschel M, van Essen D, Rodriguez $\mathrm{P}$, Zhang X, Guyot B, Roeder RG, Borggrefe T. 2006. The mediator complex functions as a coactivator for GATA-1 in erythropoiesis via subunit Med1/ TRAP220. Proc Natl Acad Sci 103: 18504-18509.

Stumpf M, Yue X, Schmitz S, Luche H, Reddy JK, Borggrefe T. 2010. Specific erythroid-lineage defect in mice conditionally deficient for mediator subunit Med1. Proc Natl Acad Sci 107: 21541-21546.

Sugiyama D, Tanaka M, Kitajima K, Zheng J, Yen H, Murotani T, Yamatodani A, Nakano T. 2008. Differential context-dependent effects of friend of GATA-1 (FOG-1) on mast-cell development and differentiation. Blood 111: 1924-1932.

Svensson EC, Tufts RL, Polk CE, Leiden JM. 1999. Molecular cloning of FOG-2: A modulator of transcription factor GATA-4 in cardiomyocytes. Proc Natl Acad Sci 96: 956-961.

Tanabe O, Katsuoka F, Campbell AD, Song W, Yamamoto M, Tanimoto K, Engel JD. 2002. An embryonic/fetal $\beta$-type globin gene repressor contains a nuclear receptor TR2/ TR4 heterodimer. EMBO J 21: 3434-3442.

Tanabe O, McPhee D, Kobayashi S, Shen Y, Brandt W, Jiang X, Campbell AD, Chen YT, Chang C, Yamamoto $M$, et al. 2007. Embryonic and fetal $\beta$-globin gene repression by the orphan nuclear receptors, TR2 and TR4. EMBO J 26: 2295-2306.

Tevosian SG, Deconinck AE, Cantor AB, Rieff HI, Fujiwara Y, Corfas G, Orkin SH. 1999. FOG-2: A novel GATA-family cofactor related to multitype zinc-finger proteins Friend of GATA-1 and U-shaped. Proc Natl Acad Sci 96: 950-955. 
K.R. Katsumura et al.

Tevosian SG, Deconinck AE, Tanaka M, Schinke M, Litovsky SH, Izumo S, Fujiwara Y, Orkin SH. 2000. FOG-2, a cofactor for GATA transcription factors, is essential for heart morphogenesis and development of coronary vessels from epicardium. Cell 101: 729-739.

Towatari M, Ciro M, Ottolenghi S, Tsuzuki S, Enver T. 2004. Involvement of mitogen-activated protein kinase in the cytokine-regulated phosphorylation of transcription factor GATA-1. Hematol J 5: 262-272.

Tripic T, Deng W, Cheng Y, Zhang Y, Vakoc CR, Gregory GD, Hardison RC, Blobel GA. 2009. SCL and associated proteins distinguish active from repressive GATA transcription factor complexes. Blood 113: 2191-2201.

Tsai SF, Martin DI, Zon LI, D’Andrea AD, Wong GG, Orkin SH. 1989. Cloning of cDNA for the major DNAbinding protein of the erythroid lineage through expression in mammalian cells. Nature 339: 446-451.

Tsai FY, Keller G, Kuo FC, Weiss M, Chen J, Rosenblatt M, Alt FW, Orkin SH. 1994. An early haematopoietic defect in mice lacking the transcription factor GATA-2. Nature 371: $221-226$.

Tsang AP, Visvader JE, Turner CA, Fujiwara Y, Yu C, Weiss MJ, Crossley M, Orkin SH. 1997. FOG, a multitype zinc finger protein, acts as a cofactor for transcription factor GATA-1 in erythroid and megakaryocytic differentiation. Cell 90: 109-119.

Tsang AP, Fujiwara Y, Hom DB, Orkin SH. 1998. Failure of megakaryopoiesis and arrested erythropoiesis in mice lacking the GATA-1 transcriptional cofactor FOG. Genes Dev 12: 1176-1188.

Tuan D, London IM. 1984. Mapping of DNase I-hypersensitive sites in the upstream DNA of human embryonic $\varepsilon$-globin gene in K562 leukemia cells. Proc Natl Acad Sci 81: 2718-2722.

Uda M, Galanello R, Sanna S, Lettre G, Sankaran VG, Chen W, Usala G, Busonero F, Maschio A, Albai G, et al. 2008. Genome-wide association study shows BCL11A associated with persistent fetal hemoglobin and amelioration of the phenotype of $\beta$-thalassemia. Proc Natl Acad Sci 105: 1620-1625.

Vakoc CR, Letting DL, Gheldof N, Sawado T, Bender MA, Groudine M, Weiss MJ, Dekker J, Blobel GA. 2005. Proximity among distant regulatory elements at the $\beta$-globin locus requires GATA- 1 and FOG-1. Mol Cell 17: 453-462.

Vyas P, Ault K, Jackson CW, Orkin SH, Shivdasani RA. 1999. Consequences of GATA-1 deficiency in megakaryocytes and platelets. Blood 93: 2867-2875.

Wahlberg K, Jiang J, Rooks H, Jawaid K, Matsuda F, Yamaguchi M, Lathrop M, Thein SL, Best S. 2009. The HBS1L-MYB intergenic interval associated with elevated $\mathrm{HbF}$ levels shows characteristics of a distal regulatory region in erythroid cells. Blood 114: 1254-1262.

Watanapokasin Y, Chuncharunee S, Sanmund D, Kongnium W, Winichagoon P, Rodgers GP, Fucharoen S. 2005. In vivo and in vitro studies of fetal hemoglobin induction by hydroxyurea in $\beta$-thalassemia/hemoglobin E patients. Exp Hematol 33: 1486-1492.

Weatherall DJ. 2010. The inherited diseases of hemoglobin are an emerging global health burden. Blood 115: $4331-4336$.

Wechsler J, Greene M, McDevitt MA, Anastasi JJEK, LeBeau MM, Crispino JD. 2002. Acquired mutations in
GATA-1 in the megakaryoblastic leukemia of Down syndrome. Nat Genet 32: 148-152.

Weinberg RS, Ji X, Sutton M, Perrine S, Galperin Y, Li Q, Liebhaber SA, Stamatoyannopoulos G, Atweh GF. 2005. Butyrate increases the efficiency of translation of $\gamma$-globin mRNA. Blood 105: 1807-1809.

Weiss MJ, Orkin SH. 1995. Transcription factor GATA-1 permits survival and maturation of erythroid precursors by preventing apoptosis. Proc Natl Acad Sci 92: 96239627.

Weiss MJ, Keller G, Orkin SH. 1994. Novel insights into erythroid development revealed through in vitro differentiation of GATA-1 embryonic stem cells. Genes Dev 8: $1184-1197$.

Weiss MJ, Yu C, Orkin SH. 1997. Erythroid-cell-specific properties of transcription factor GATA-1 revealed by phenotypic rescue of a gene-targeted cell line. Mol Cell Biol 17: 1642-1651.

Welch JJ, Watts JA, Vakoc CR, Yao Y, Wang H, Hardison RC, Blobel GA, Chodosh LA, Weiss MJ. 2004. Global regulation of erythroid gene expression by transcription factor GATA-1. Blood 104: 3136-3147.

Wilber A, Nienhuis AW, Persons DA. 2011. Transcriptional regulation of fetal to adult hemoglobin switching: New therapeutic opportunities. Blood 117: 3945-3953.

Wilson DB, Dorfman DM, Orkin SH. 1990. A nonerythroid GATA-binding protein is required for function of the human preproendothelin-1 promoter in endothelial cells. Mol Cell Biol 10: 4854-4862.

Wozniak RJ, Keles S, Lugus JJ, Young KH, Boyer ME, Tran TM, Choi K, Bresnick EH. 2008. Molecular hallmarks of endogenous chromatin complexes containing master regulators of hematopoiesis. Mol Cell Biol 28: 6681-6694.

Wu W, Cheng Y, Keller CA, Ernst J, Kumar SA, Mishra T, Morrissey C, Dorman CM, Chen KB, Drautz D, et al. 2011. Dynamics of the epigenetic landscape during erythroid differentiation after GATA1 restoration. Genome Res 21: 1659-1671.

Xu J, Sankaran VG, Ni M, Menne TF, Puram RV, Kim W, Orkin SH. 2010. Transcriptional silencing of $\boldsymbol{\gamma}$-globin by BCL11A involves long-range interactions and cooperation with SOX6. Genes Dev 24: 783-798.

Xu J, Peng C, Sankaran VG, Shao Z, Esrick EB, Chong BG, Ippolito GC, Fujiwara Y, Ebert BL, Tucker PW, et al. 2011. Correction of sickle cell disease in adult mice by interference with fetal hemoglobin silencing. Science 334: 993-996.

Yamamoto M, Ko LJ, Leonard MW, Beug H, Orkin SH, Engel JD. 1990. Activity and tissue-specific expression of the transcription factor NF-E1 multigene family. Genes Dev 4: 1650-1662.

Yao X, Kodeboyina S, Liu L, Dzandu J, Sangerman J, OforiAcquah SF, Pace BS. 2009. Role of STAT3 and GATA-1 interactions in $\gamma$-globin gene expression. Exp Hematol 37: 889-900.

Yi Z, Cohen-Barak O, Hagiwara N, Kingsley PD, Fuchs DA, Erickson DT, Epner EM, Palis J, Brilliant MH. 2006. Sox6 directly silences $\varepsilon$ globin expression in definitive erythropoiesis. PLoS Genet 2: e14. 
Yu C, Cantor AB, Yang H, Browne C, Wells RA, Fukiwara Y, Orkin SH. 2002. Targeted deletion of a high-affinity GATA-binding site in the GATA-1 promoter leads to selective loss of the eosinophil lineage in vivo. J Exp Med 195: 1387-1395.

Yu YL, Chiang YJ, Chen YC, Papetti M, Juo CG, Skoultchi AI, Yen JJ. 2005. MAPK-mediated phosphorylation of GATA-1 promotes Bcl-XL expression and cell survival. J Biol Chem 280: 29533-29542.

Yu M, Riva L, Xie H, Schindler Y, Moran TB, Cheng Y, Yu D, Hardison R, Weiss MJ, Orkin SH, et al. 2009. Insights into GATA-1-mediated gene activation versus repression via genome-wide chromatin occupancy analysis. Mol Cell 36: 682-695.

Yu Y, Wang J, Khaled W, Burke S, Li P, Chen X, Yang W, Jenkins NA, Copeland NG, Zhang S, et al. 2012. Bcl11a is essential for lymphoid development and negatively regulates p53. J Exp Med 209: 2467-2483.

Zhao W, Kitidis C, Fleming MD, Lodish HF, Ghaffari S. 2006. Erythropoietin stimulates phosphorylation and activation of GATA-1 via the PI3-kinase/AKT signaling pathway. Blood 107: 907-915.

Zhou D, Pawlik KM, Ren J, Sun CW, Townes TM. 2006. Differential binding of erythroid Krupple-like factor to
Mechanisms Underlying Hemoglobin Synthesis

embryonic/fetal globin gene promoters during development. J Biol Chem 281: 16052-16057.

Zhou D, Liu K, Sun CW, Pawlik KM, Townes TM. 2010. KLF1 regulates BCL11A expression and $\gamma$ - to $\beta$-globin gene switching. Nat Genet 42: 742-744.

Zhu X, Wang Y, Pi W, Liu H, Wickrema A, Tuan D. 2012. NF$\mathrm{Y}$ recruits both transcription activator and repressor to modulate tissue- and developmental stage-specific expression of human $\gamma$-globin gene. PLoS ONE 7: e47175.

Zohren F, Souroullas GP, Luo M, Gerdemann U, Imperato MR, Wilson NK, Gottgens B, Lukov GL, Goodell MA. 2012. The transcription factor Lyl-1 regulates lymphoid specification and the maintenance of early $\mathrm{T}$ lineage progenitors. Nat Immunol 13: 761-769.

Zon LI, Tsai SF, Burgess S, Matsudaira P, Bruns GA, Orkin SH. 1990. The major human erythroid DNA-binding protein (GF-1): Primary sequence and localization of the gene to the X chromosome. Proc Natl Acad Sci 87: $668-672$.

Zon LI, Gurish MF, Stevens RL, Mather C, Reynolds DS, Austen KF, Orkin SH. 1991. GATA-binding transcription factors in mast cells regulate the promoter of the mast cell carboxypeptidase A gene. J Biol Chem 266: 22948-22953. 


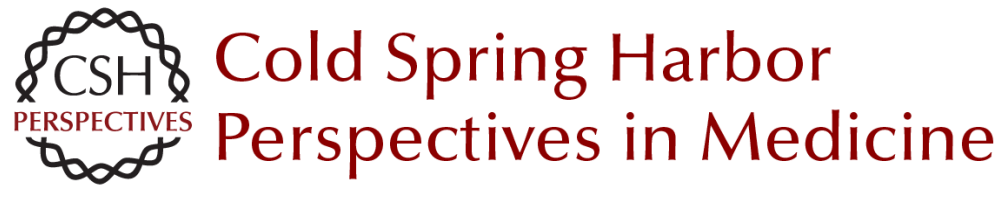

\section{Transcriptional Mechanisms Underlying Hemoglobin Synthesis}

Koichi R. Katsumura, Andrew W. DeVilbiss, Nathaniel J. Pope, Kirby D. Johnson and Emery H. Bresnick Cold Spring Harb Perspect Med 2013; doi: 10.1101/cshperspect.a015412 originally published online July 9, 2013

\section{Subject Collection Hemoglobin and Its Diseases}

The Natural History of Sickle Cell Disease Graham R. Serjeant

\section{Current Management of Sickle Cell Anemia} Patrick T. McGann, Alecia C. Nero and Russell E. Ware

Cell-Free Hemoglobin and Its Scavenger Proteins: New Disease Models Leading the Way to Targeted Therapies Dominik J. Schaer and Paul W. Buehler

Clinical Manifestations of $\alpha$-Thalassemia Elliott $P$. Vichinsky

Erythroid Heme Biosynthesis and Its Disorders Harry A. Dailey and Peter N. Meissner

Hemoglobin Variants: Biochemical Properties and Clinical Correlates Christopher S. Thom, Claire F. Dickson, David A. Gell, et al.

The Prevention of Thalassemia Antonio Cao and Yuet Wai Kan

The Switch from Fetal to Adult Hemoglobin Vijay G. Sankaran and Stuart H. Orkin
Transcriptional Mechanisms Underlying Hemoglobin Synthesis

Koichi R. Katsumura, Andrew W. DeVilbiss, Nathaniel J. Pope, et al.

Iron Deficiency Anemia: A Common and Curable Disease Jeffery L. Miller

Management of the Thalassemias Nancy F. Olivieri and Gary M. Brittenham

The Molecular Basis of $\beta$-Thalassemia Swee Lay Thein

Erythropoiesis: Development and Differentiation Elaine Dzierzak and Sjaak Philipsen

Erythropoietin

H. Franklin Bunn

Classification of the Disorders of Hemoglobin Bernard G. Forget and H. Franklin Bunn

The Molecular Basis of $\alpha$-Thalassemia Douglas R. Higgs

For additional articles in this collection, see http://perspectivesinmedicine.cshlp.org/cgi/collection/ 